\title{
Synthesis, Characterization, and DNA-Binding Kinetics of New Pd(II) and Pt(II) Thiosemicarbazone Complexes: Spectral, Structural, and Anticancer Evaluation
}

\author{
Simon N. Mbugua ${ }^{D},{ }^{1}$ Lydia W. Njenga, ${ }^{1}$ Ruth A. Odhiambo, ${ }^{1}$ Shem O. Wandiga, \\ Mervin Meyer $\mathbb{D},{ }^{2}$ Nicole Sibuyi $\mathbb{D}^{2},{ }^{2}$ Roger A. Lalancette, ${ }^{3}$ and Martin O. Onani $\mathbb{D}^{4}$ \\ ${ }^{1}$ Department of Chemistry, University of Nairobi, P.O. Box 30197-00100, Nairobi, Kenya \\ ${ }^{2}$ Department of Biotechnology, University of the Western Cape, Private Bag X17, Belville 7535, South Africa \\ ${ }^{3}$ Department of Chemistry, Rutgers University, 73 Warren St., Newark, NJ 07102, USA \\ ${ }^{4}$ Department of Chemical Sciences, University of the Western Cape, Private Bag X17, Belville 7535, South Africa
}

Correspondence should be addressed to Simon N. Mbugua; mbuguasn@students.uonbi.ac.ke

Received 2 December 2019; Revised 22 April 2020; Accepted 22 May 2020; Published 27 June 2020

Academic Editor: Michele Benedetti

Copyright $\odot 2020$ Simon N. Mbugua et al. This is an open access article distributed under the Creative Commons Attribution License, which permits unrestricted use, distribution, and reproduction in any medium, provided the original work is properly cited.

\begin{abstract}
In a bid to come up with potential anticancer agents, a class of thiosemicarbazone ligands bearing substituted thiophene were synthesized followed by complexation with various $\mathrm{Pd}(\mathrm{II})$ and $\mathrm{Pt}(\mathrm{II})$ metal precursors. The ligands (E)-1-((thiophen-2-yl) methylene)thiosemicarbazide (L1), (E)-1-((4-bromothiophen-2-yl)methylene)thiosemicarbazide (L2), and (E)-1-((5-bromothiophen-2-yl)methylene)thiosemicarbazide (L3) were synthesized by condensation reactions and obtained in good yields. Complexation of $\mathbf{L} \mathbf{1}$ and $\mathbf{L} \mathbf{2}$ with $\mathrm{Pd}(\mathrm{cod}) \mathrm{Cl}_{2}$ gave $\mathbf{C 1}\left(\mathrm{C}_{6} \mathrm{H}_{7} \mathrm{Cl}_{2} \mathrm{~N}_{3} \mathrm{PdS}_{2}\right)$ and $\mathbf{C} \mathbf{2}\left(\mathrm{C}_{6} \mathrm{H}_{6} \mathrm{BrCl}_{2} \mathrm{~N}_{3} \mathrm{PdS}_{2}\right)$, respectively. Complexation of $\mathbf{L 1}$ with $\mathrm{K}_{2} \mathrm{PtCl}_{4}$ gave $\mathbf{C} \mathbf{3}\left(\mathrm{C}_{6} \mathrm{H}_{7} \mathrm{Cl}_{2} \mathrm{~N}_{3} \mathrm{PtS}_{2}\right)$, while $\mathbf{L} \mathbf{3}$ with $\mathrm{K}_{2} \mathrm{PtCl}_{2}\left[(\mathrm{PPh})_{3}\right]_{2}$ gave $\mathbf{C} 4\left(\mathrm{C}_{24} \mathrm{H}_{21} \mathrm{BrClN}_{3} \mathrm{PPtS}\right)$. The structures and coordination for all compounds were established by FTIR, ${ }^{1} \mathrm{H}-\mathrm{NMR},{ }^{13} \mathrm{C}-\mathrm{NMR}$, UV-Vis, elemental analysis, and single-crystal $\mathrm{X}$-ray diffraction studies for ligand L1. Tuning of the spectral and anticancer activity of the compounds was investigated by changing the position of the bromide substituent, metal center, and the $\sigma$ or $\pi$-donor/acceptor strength of the groups surrounding the metal center. The compounds had low to moderate anticancer potency with their spectral and structural properties correlating with the corresponding anticancer activity profiles. DNA binding modes were studied by spectroscopy and were comparable to known DNA intercalators. Structure-activity profiles were evident especially between $\mathbf{C} \mathbf{1}$ and $\mathbf{C} 2$ differing by the presence of a Br in position 5 of thiophene ring, which caused a remarkable increase in $\mathrm{IC}_{50}$ values, from $14.71 \pm 0.016$ (C1) to 43.08 \pm 0.001 (C2) in Caco-2 cells, $1.973 \pm 0.048(\mathbf{C 1})$ to $59.56 \pm 0.010(\mathbf{C 2})$ in MCF-7 cells, $16.65 \pm 0.051$ (C1) to $72.25 \pm 0.003$ (C2) in HeLa cells, $14.64 \pm 0.037$ (C1) to $94.34 \pm 0.003(\mathbf{C 2})$ in HepG2, and $14.05 \pm 0.042(\mathbf{C 1})$ to $>100(\mathbf{C 2})$ in PC-3 cells.
\end{abstract}

\section{Introduction}

Cancer is the second leading cause of death globally, with an estimated 1 in 6 deaths, and is responsible for an estimated 9.6 million deaths in 2018 [1]. It is estimated that approximately $70 \%$ of all deaths are cancer-related and occur in low- and middle-income countries [1]. The economic impact of cancer is significant and is increasing with a total annual economic cost of cancer in 2010 estimated at approximately US\$ 1.16 trillion. Only 1 in 5 low- and middle-income countries have the necessary data to drive cancer policy [1]. Although major steps have been made in medicine, many difficulties still need to be resolved in order to boost cancer therapy. In line with this, research is putting a great deal of effort into discovering new and effective therapeutics that can mitigate the pertinent adverse effects. Many research reports have focused on creating alternative treatments to minimize the side effects of traditional medicines over the past decade [2-4]. 
The most practiced efforts to combat cancer include surgery, chemotherapy using chemical drugs, and radiotherapy using electromagnetic radiation like X-rays to kill cancerous cells. New strategies like gene therapy are still being developed where genes from donors are inserted into the DNA of a patient to boost recognition of cancerous cells by the body's diseases fighting mechanisms. Some of the most successful chemotherapeutic drugs include those derived from metals like platinum, ruthenium, titanium, and palladium, among others.

Research on thiosemicarbazone compounds for medical applications appeared as early as 1950s when they were used against TB and leprosy [5]. The following decade saw these compounds tested for antiviral properties which were confirmed, leading to intense research which eventually culminated to the commercialization of some thiosemicarbazone products under trade names methisazone and Marboran ${ }^{\circledR}$, in the treatment of smallpox [6]. Another major step in utilization of these compounds was the publication of the first antitumor tests [7]. Finch and coworkers explored the broad areas of application where thiosemicarbazones have received most attention, classifying them in relation to their activities against cancerous cells, protozoa, bacteria, or viruses. Their activity is found to correlate to the type of metal center [8]. As anticancer agents, the activity is shown to substantially increase for the complexed product as compared to the free ligand, and also, the undesirable cytotoxicity as side effects was shown to be minimized in the complexes [8].

This work reports the anticancer activity of newly synthesized $\mathrm{Pd}(\mathrm{II})$ and $\mathrm{Pt}(\mathrm{II})$ complexes bearing thiosemicarbazone ligands. The main objectives were to evaluate the tuning of structure-activity relationships vis-à-vis different $\sigma$ and/or $\pi$-donor/acceptor properties of the groups attached to the metal center, their anticancer activities, and their binding modes to DNA.

Anticancer and apoptotic properties were performed in vitro using human colon (Caco-2), human cervical (HeLa), human hepatocellular carcinoma (HepG2), breast cancer (MCF-7), human prostate (PC-3), and noncancer human breast (MCF-12A) cells. Binding modes to DNA were studied by use of calf thymus DNA (CT-DNA). A crystal structure of one of the ligands, $\mathbf{L 1}$, is also reported here for the first time according to the CCCD database.

\section{Materials and Methods}

All synthetic manipulations were performed under the fume hood under inert conditions. The solvents were of analytical grade, and each was dried with the recommended drying agent and distilled prior to use. All reagents used in the syntheses were of analytical grade procured from SigmaAldrich or Merk Chemicals and used without further modifications.

The melting points were determined on open capillaries using SMP-10 melting point apparatus. FTIR spectra were recorded using PerkinElmer Spectrum 100 Series ATR or FT-IR instrument on $\mathrm{KBr}$ pellets in the range
$4000-400 \mathrm{~cm}^{-1}$. Proton and carbon-13 nuclear magnetic resonance spectra were obtained from the Bruker $400 \mathrm{MHz}$ spectrometer. The chemical shifts were measured in ppm relative to a TMS standard. UV-Vis spectra were recorded in DMSO solvent at a range of $200-800 \mathrm{~nm}$. Bioassays on the anticancer efficacy were performed at the Department of Biotechnology at the University of the Western Cape. The elemental microanalysis was performed on Server 112 series Elemental Analyzer at the University of Stellenbosch. The single crystal X-ray crystallography was performed at Rutgers University, USA, using a Bruker SMART CCD Apex-II area-detector.

The complexes (C1-C4) were tested against human cell lines: Caco-2 (human colon), HeLa (human cervical), HepG2 (human hepatocellular), MCF-7 (breast cancer), PC-3 (human prostate), and MCF-12A (noncancer human breast) cells. The cells were cultured in their respective media supplemented with $10 \%$ fetal bovine serum (FBS) and $1 \%$ pen-strep cocktail $(100 \mathrm{U} / \mathrm{mL}$ penicillin and $100 \mathrm{~g} /$ mL streptomycin). Caco-2, HeLa, HepG2, and MCF-7 cells were grown in Dulbecco's Modified Eagle Medium and MCF-12A in DMEM-F12 containing insulin, EGF, and hydrocortisone, while PC-3 cells were cultured in RPMI1640 media. The cells were grown at $37^{\circ} \mathrm{C}$ in a $5 \% \mathrm{CO}_{2}$ humidified incubator (Labotec, South Africa) and seeded at $1 \times 10^{5}$ cells $/ \mathrm{mL}$ density in a 96 -well plate for $24 \mathrm{~h}$. The cells were treated with $100 \mu \mathrm{g} / \mathrm{mL}$ of the test compound for $24 \mathrm{~h}$ period. Cytotoxicity of the compounds was assessed by MTT assay following manufacturer's instructions. After treatment, $10 \mu \mathrm{L}$ of $5 \mathrm{mg} / \mathrm{mL}$ MTT (Sigma, USA) was added to each well, and the plates were incubated at $37^{\circ} \mathrm{C}$ for $3 \mathrm{~h}$. The insoluble formazan crystals were solubilised by adding $100 \mu \mathrm{L}$ of DMSO. The reduction of MTT was read at $570 \mathrm{~nm}$ using POLARStar Omega plate reader.

\subsection{Synthesis of the Ligands}

2.1.1. (E)-1-((Thiophen-2-yl)methylene)thiosemicarbazide (L1). The ligand was synthesized using the method described by Channar et al. [9] with some modifications. Thiophene-2carbaldehyde $(475 \mu \mathrm{l}(5 \mathrm{mmol}))$ and thiosemicarbazide $(0.4558 \mathrm{~g}(5 \mathrm{mmol}))$ were refluxed under inert conditions in $20 \mathrm{ml}$ dry methanol for 12 hours. On cooling, a light brown precipitate was formed which was redissolved in diethyl ether, filtered on activated carbon, and kept in the fridge for slow evaporation where shiny brown crystals were obtained.

Yield: 54\%. FTIR (KBr $\left.v^{-1}\right)$; (3414-3149 N-H stretch) 3000 ( $\mathrm{sp}^{2} \mathrm{C}-\mathrm{H}$ bend), $1611 \mathrm{CH}=\mathrm{N}$ stretch, and $1538 \mathrm{C}=\mathrm{S}$ stretch.

${ }^{1} \mathrm{H}-\mathrm{NMR} \quad(400 \mathrm{MHz}, \quad$ DMSO-d 6 ) $\delta 11.45 \quad(\mathrm{~s}, \quad 1 \mathrm{H})$, 8.09-8.33 (m, 1H), $7.65(\mathrm{~d}, J=5.01 \mathrm{~Hz}, 1 \mathrm{H}), 7.45$ (dd, $J=0.73,3.55 \mathrm{~Hz}, 1 \mathrm{H}), 7.12(\mathrm{dd}, J=3.67,5.01 \mathrm{~Hz}, 1 \mathrm{H})$, and 3.35 (s, 2H).

${ }^{13}$ C-NMR (400 MHz, DMSO-d6) $\delta 178.27$ (C=N imine), $139.24,138.22,130.92,129.33$, and 128.41.

Molecular weight: 185.27. Elemental analysis; molecular formula; $\mathrm{C}_{6} \mathrm{H}_{7} \mathrm{~N}_{3} \mathrm{~S}_{2}$. Calculated (obtained); C, 38.90(38.83); H, 3.81(3.87); N, 22.68(22.63); and S, 34.61(34.63). 
2.1.2. (E)-1-((5-Bromothiophen-2-yl)methylene)thiosemicar bazide (L2). The ligand was synthetized with a synthetic procedure similar for L1 using 4-bromothiophene-2-carbaldehyde $(625 \mu \mathrm{l}(5 \mathrm{mmol}))$ and thiosemicarbazide $(0.4558 \mathrm{~g}(5 \mathrm{mmol}))$. The ligand was isolated as a light brown precipitate.

Yield 68\%. FTIR (KBr $\left.v^{-1}\right)$; (3429-3276 N-H stretch), 3155-2999 ( $\mathrm{sp}^{2} \mathrm{C}-\mathrm{H}$ bend), $1608 \mathrm{CH}=\mathrm{N}$ stretch, and 1543 $\mathrm{C}=\mathrm{S}$ stretch. ${ }^{1} \mathrm{H}-\mathrm{NMR}\left(400 \mathrm{MHz}, \mathrm{DMSO}-\mathrm{d}_{6}\right) \delta 11.50(\mathrm{~s}$, $1 \mathrm{H}), 8.14$ (s, 1H), 7.64 (br. s., $1 \mathrm{H}), 7.24$ (s, 1H), and 3.35 (s, $2 \mathrm{H})$.

${ }^{13} \mathrm{C}-\mathrm{NMR}(400 \mathrm{MHz}, \mathrm{DMSO}-\mathrm{d} 6) \delta 184.27(\mathrm{C}=\mathrm{N}$ imine $)$, 178.25 141.07, 137.29, 131.58, and 115.03.

Molecular weight: 264.17. Elemental analysis; molecular formula; $\mathrm{C}_{6} \mathrm{H}_{6} \mathrm{BrN}_{3} \mathrm{~S}_{2}$. Calculated (obtained); C, 27.28(27.26); H, 2.29(2.27); N, 15.91(15.96); and S, 24.28(25.27).

2.1.3. (E)-1-((4-Bromothiophen-2-yl)methylene)thiosemicar bazide (L3). The ligand was synthetized with a synthetic procedure similar to $\mathbf{L 1}$ using 4-bromothiophene-2-carbaldehyde $(1.061 \mathrm{~g}(5 \mathrm{mmol}))$ and thiosemicarbazide $(0.4558 \mathrm{~g}(5 \mathrm{mmol}))$. The ligand was isolated as a light brown powder.

Yield 58\%. FTIR (KBr $\left.v^{-1}\right)$; (3378-3246 N-H stretch), 3155-3008 (sp ${ }^{2} \mathrm{C}-\mathrm{H}$ bend), $1605 \mathrm{CH}=\mathrm{N}$ stretch, and 1545 $\mathrm{C}=\mathrm{S}$ stretch. ${ }^{1} \mathrm{H}-\mathrm{NMR}\left(400 \mathrm{MHz}, \mathrm{DMSO}-\mathrm{d}_{6}\right) \delta 11.54(\mathrm{~s}$, $1 \mathrm{H}), 8.16(\mathrm{~s}, 1 \mathrm{H}), 7.75$ (s, 1H), $7.53(\mathrm{~s}, 1 \mathrm{H})$, and $3.34(\mathrm{~s}, 2 \mathrm{H})$. ${ }^{13} \mathrm{C}-\mathrm{NMR}\left(400 \mathrm{MHz}, \mathrm{DMSO}-\mathrm{d}_{6}\right) \delta 178.27$ ( $\mathrm{C}=\mathrm{N}$ imine), $140.80,136.35,132.21,126.46$, and 109.97.

Molecular weight: 264.17. Elemental analysis; molecular formula; $\mathrm{C}_{6} \mathrm{H}_{6} \mathrm{BrN}_{3} \mathrm{~S}_{2}$. Calculated (obtained); C, 27.28 (27.22); H, 2.29 (2.24); N, 15.91 (15.87); and S, 24.28 (24.27).

\subsection{Synthesis of $P d(I I)$ Complexes}

2.2.1. Synthesis of Pd(II) Complex (C1). The ligand L1 $92 \mathrm{mg}$ $(0.25 \mathrm{mmol})$ was dissolved in THF $(2 \mathrm{ml})$ and was added dropwise into a stirring solution of $\mathrm{Pd}(\operatorname{cod}) \mathrm{Cl}_{2}(72 \mathrm{mg}$ $(0.25 \mathrm{mmol}))$ dissolved in DCM $(15 \mathrm{ml})$ under argon. A red precipitate was formed, and stirring was continued at room temperature for 6 hours while monitoring the reaction with TLC until completion. The solvent was reduced under pressure to about $1 \mathrm{ml}$. Excess hexane was added followed by filtration and washing of the red powder product with more hexane $(3 \times 5 \mathrm{ml})$ followed by filtration and drying under vacuum.

Yield 71\%. FTIR $\left(\mathrm{KBr} v^{-1}\right)$; 3370, NH stretch; 3176-3076, CH stretch, 1619, $\mathrm{C}=\mathrm{N}, 1542 ; \mathrm{C}=\mathrm{S}$ stretch. ${ }^{1} \mathrm{H}-\mathrm{NMR}\left(400 \mathrm{MHz}, \mathrm{DMSO}-\mathrm{d}_{6}\right) \delta 8.35-8.60(\mathrm{~m}, 1 \mathrm{H}), 7.98$ (s, $1 \mathrm{H}), 7.84(\mathrm{~s}, 1 \mathrm{H}), 7.51$ (br. s., $1 \mathrm{H}), 7.13$ (d, $J=4.89 \mathrm{~Hz}$, $1 \mathrm{H})$, and $3.60(\mathrm{~s}, 2 \mathrm{H}) .{ }^{13} \mathrm{C}-\mathrm{NMR}\left(400 \mathrm{MHz}, \mathrm{DMSO}-\mathrm{d}_{6}\right) \delta$ 177.24 ( $\mathrm{C}=\mathrm{N}$ imine), 172.16, 146.15, 135.36, 133.53, and 127.13.

Molecular weight: 362.6. Elemental analysis; molecular formula; $\mathrm{C}_{6} \mathrm{H}_{7} \mathrm{Cl}_{2} \mathrm{~N}_{3} \mathrm{PdS}_{2}$. Calculated (obtained); C, 19.87 (19.77); H, 1.95 (1.96); and N, 11.59 (11.52).
2.2.2. Synthesis of $P d(I I)$ Complex (C2). The complex was synthesized with a procedure similar to C1 using L2 $(66 \mathrm{mg}(0.25 \mathrm{mmol}))$. The complex was isolated as a brown powder.

Yield 74\%. FTIR (KBr $\left.v^{-1}\right) ; 3075, \mathrm{NH}$ stretch; $2943 \mathrm{CH}$ stretch; $1621 \mathrm{C}=\mathrm{N}$; and $1419 \mathrm{C}=\mathrm{S}$ stretch. ${ }^{1} \mathrm{H}-\mathrm{NMR}$ $\left(400 \mathrm{MHz}, \mathrm{DMSO}-\mathrm{d}_{6}\right) \delta 8.34(\mathrm{~s}, 1 \mathrm{H}), 7.59(\mathrm{~s}, 1 \mathrm{H}), 7.32(\mathrm{~s}$, $1 \mathrm{H}), 6.97$ (s, $1 \mathrm{H}), 5.76(\mathrm{~s}, 1 \mathrm{H})$, and 3.60 (br. s., $2 \mathrm{H}) .{ }^{13} \mathrm{C}-$ NMR (400 MHz, DMSO-d 6 ) $\delta 172.83$ (C= N imine), 144.86, 136.01, 134.09, 130.64, and 124.92.

Molecular weight: 441.49. Elemental analysis; molecular formula; $\mathrm{C}_{6} \mathrm{H}_{6} \mathrm{BrCl}_{2} \mathrm{~N}_{3} \mathrm{PdS}_{2}$. Calculated (obtained); C, 16.32 (16.36); H, 1.37 (1.31); N, 9.52 (9.45); and S, 14.53 (14.57).

Molecular weight: 387.2. Elemental analysis; molecular formula; $\mathrm{C}_{12} \mathrm{H}_{13} \mathrm{ClN}_{4} \mathrm{PdS}$. Calculated (obtained); C, 37.22 (37.27); H, 3.38 (2.33); N, 14.47 (14.42); and S, 8.28 (8.27).

\subsection{Synthesis of Pt(II) Complexes}

2.3.1. Synthesis of Pt(II) Complex (C3). The complex was synthesized by dropwise addition of a solution of $\mathrm{K}_{2} \mathrm{PtCl}_{4}$ (104 mg (0.25 mmol)) dissolved in $\mathrm{MeOH} / \mathrm{H}_{2} \mathrm{O}(2: 1)(3 \mathrm{ml})$, into a stirring solution of $\mathbf{L 1}(46 \mathrm{mg}(0.25 \mathrm{mmol}))$ in THF $(2 \mathrm{ml})$. A yellow precipitate was formed immediately, and stirring was continued for one and half hours at room temperature, filtered followed by washing with diethyl ether $(3 \times 5 \mathrm{ml})$ and dried under vacuum.

Yield 98\%. FTIR (KBr $\left.v^{-1}\right)$; 3268, NH stretch; 3082, CH stretch; 1593, $\mathrm{C}=\mathrm{N} ; 1515, \mathrm{C}=\mathrm{S}$ stretch. ${ }^{1} \mathrm{H}-\mathrm{NMR}(400 \mathrm{MHz}$, DMSO-d 6 ) $\delta 12.34$ (br. s., $1 \mathrm{H}), 8.55$ (s, $1 \mathrm{H}), 7.60$ (br. s., $1 \mathrm{H}$ ), 7.16 (br. s., $1 \mathrm{H}), 6.95$ (s, $1 \mathrm{H}$ ), and 3.46 (br. s., $2 \mathrm{H}) .{ }^{13} \mathrm{C}-\mathrm{NMR}$ (400 MHz, DMSO- $\left.\mathrm{d}_{6}\right) \delta 173.45(\mathrm{C}=\mathrm{N}$ imine), 145.86, 143.94, 136.93, 133.14, and 127.79.

Molecular weight: 451.25. Elemental analysis; molecular formula; $\mathrm{C}_{6} \mathrm{H}_{7} \mathrm{Cl}_{2} \mathrm{~N}_{3} \mathrm{PtS}_{2}$. Calculated (obtained); C, 15.97 (15.91); H, 1.56 (1.51); N, 9.31 (9.38); and S, 14.21 (14.26).

2.3.2. Synthesis of Pt(II) Complex (C4). The complex was synthesized following the procedure for the previous one by adding of $\mathrm{PtCl}_{2}\left[\left(\mathrm{PPh}_{3}\right)_{2}\right]_{2}(198 \mathrm{mg}(0.25 \mathrm{mmol}))$ in $\mathrm{DCM}$ $(5 \mathrm{ml})$ into a stirring solution of $\mathbf{L 2}(66 \mathrm{mg}(0.25 \mathrm{mmol}))$ in benzene $(20 \mathrm{ml})$ at room temperature and stirred for $24 \mathrm{~h}$. The complex was isolated as a yellow powder.

Yield 36\%. FTIR (KBr $\left.v^{-1}\right)$; (3287-3166 N-H stretch), 3076-2958 ( $\mathrm{sp}^{2} \mathrm{C}-\mathrm{H}$ bend), $1608 \mathrm{CH}=\mathrm{N}$ stretch, $1582 \mathrm{C}=\mathrm{S}$ stretch. ${ }^{1} \mathrm{H}-\mathrm{NMR}\left(400 \mathrm{MHz}, \mathrm{DMSO}-\mathrm{d}_{6}\right) \delta 8.72(\mathrm{~s}, 1 \mathrm{H}), 7.96$ (s, 1H), $7.43(\mathrm{~m}, 15 \mathrm{H}), 3.43(\mathrm{~s}, 1 \mathrm{H}), 2.89(\mathrm{~s}, 1 \mathrm{H})$, and $2.74(\mathrm{~s}$, 2H).

Molecular weight: 756.98. Elemental analysis; molecular formula; $\mathrm{C}_{24} \mathrm{H}_{21} \mathrm{BrClN}_{3} \mathrm{PPtS}_{2}$. Calculated (obtained); C, 38.08 (38.0); H, 2.80 (2.79); N, 5.55 (5.53); and S, 8.90 (8.87).

2.4. Crystal Structure for L1. The single crystal X-ray crystallography experiment was performed using a Bruker SMART CCD Apex-II area-detector. The crystal structure was solved and refined using the full-matrix least-square 
method based on $F^{2}[10]$ and the graphics interface program ORTEP-3 for Windows [11].

2.5. Anticancer Activity. This was performed using human colon (Caco-2), human cervical (HeLa), human hepatocellular carcinoma (HepG2), breast cancer (MCF-7), human prostate (PC-3), and noncancer human breast (MCF-12A) cancer cells in vitro by incubating the particular cancer cells with $2.2 \times 10^{-4} \mathrm{M}$ of the various compounds. Cell viability was determined after a $24 \mathrm{~h}$ period.

Attempts to complex $\mathbf{L} 2$ with $\mathrm{K}_{2} \mathrm{PtCl}_{4}$ and $\mathbf{L} \mathbf{3}$ with either $\mathrm{Pd}(\operatorname{cod}) \mathrm{Cl}_{2}$ or $\mathrm{K}_{2} \mathrm{PtCl}_{4}$ did not give a product. Similar attempts to complex $\mathbf{L 1}$ with $\mathrm{PtCl}_{2}\left[\left(\mathrm{PPh}_{3}\right)_{2}\right]_{2}$ did not yield a product.

\section{Results and Discussion}

3.1. Synthesis. The ligands L1-L3 were synthesized via Schiff base condensation reaction of thiosemicarbazide compound with an appropriate thiophene-2-carbaldehyde under reflux for 12 hours. The complexes were then formed through a reaction of the ligands with metal precursors $\mathrm{Pd}(\operatorname{cod}) \mathrm{Cl}_{2}(\mathrm{Cl}$ and C2), $\mathrm{K}_{2} \mathrm{PtCl}_{4}(\mathrm{C} 3)$, and $\mathrm{PdCl}_{2}\left(\mathrm{PPh}_{3}\right)_{2}$ (C4). These reactions are summarized under Scheme 1.

3.2. Infrared Spectra. The FTIR for the compounds were recorded in either $\mathrm{KBr}$ pellets or ATR. The IR spectrum for the ligands displayed a clear stretching vibration bands between 1605 and $1611 \mathrm{~cm}^{-1}$ which were assigned to the imine $\mathrm{C}=\mathrm{N}$ moiety. The ligand $\mathbf{L} \mathbf{1}$ has an unsubstituted thiophene and shows the highest energy for the imine bond at $1611 \mathrm{~cm}^{-1}$. On introducing a bromide at position 4 on the thiophene ring (L3), there is a hypsochromic shift of $6 \mathrm{~cm}^{-1}$ to $1605 \mathrm{~cm}^{-1}$. This is because of the electron withdrawing effect of the electronegative bromide which draws electron density away from the thiophene ring and consequently from the imine region thereby raising the single bond character of the imine bond resulting in the observed lower shift in the frequency.

The ligand $\mathbf{L} 2$ with a $-\mathrm{Br}$ introduced at position 5 on the thiophene ring showed a lesser shift in frequency $\left(3 \mathrm{~cm}^{-1}\right)$ from $1611 \mathrm{~cm}^{-1}$ to $1608 \mathrm{~cm}^{-1}$. Compared to $\mathrm{L3}$, the $-\mathrm{Br}$ at position 5 has a possible resonance donation from its lone pair of nonbonding electrons which contribute to an increased electron density to the thiophene ring and consequently to the imine region. However, the electronegativity dipole is dominant compared to the resonance dipole due to the poor overlap of $4 p-2 p$ orbitals with carbon. The FTIR spectra for the ligands are shown in Table 1.

The azomethine peaks were observed in the complexes where they were found to have shifted to between 1593 and $1637 \mathrm{~cm}^{-1}$. It was observed that, in all the Pd complexes, the azomethine peak shifted to higher energy, while for Pt(II) complexes, it shifted to lower energy in the IR spectra. For the ligands, a possible explanation to this can be deduced from a consideration of the different groups and substituents attached to the imine bond. Complexes $\mathbf{C} \mathbf{1}$ and $\mathbf{C} 3$ were compared to the parent ligand $\mathbf{L} \mathbf{1}$ after the introduction of
$\mathrm{PdCl}_{2}$ and $\mathrm{PtCl}_{2}$ salts, respectively. As mentioned earlier, complexation with $\mathrm{Pd}(\mathrm{II})$ caused a shift to higher energy by $8 \mathrm{~cm}^{-1}\left(1611 \mathrm{~cm}^{-1}\right.$ to $1619 \mathrm{~cm}^{-1}$ for $\left.\mathbf{C 1}\right)$ while complexation with $\mathrm{Pt}(\mathrm{II})$ shifted the energy to a lower wavenumber by $18 \mathrm{~cm}^{-1}\left(1593 \mathrm{~cm}^{-1}\right.$ to $1611 \mathrm{~cm}^{-1}$ for C3). This can be explained in terms of nuclear charge for the two metals. $\mathrm{Pt}$ (II) has a higher nuclear charge inferring that the incoming ligand will be attracted more to Pt than to Pd. This leaves the azomethine region with less electron density and more single bond character for the Pt(II) complex compared to the $\mathrm{Pd}$ (II) complex. Bond dissociation energies for $\mathrm{M}-\mathrm{L}$ bond is also greater for $\mathrm{Pt}$ than Pd due to less steric crowding around the Pt metal center. These factors raise the overall reactivity of $\mathrm{Pd}(\mathrm{II})$ complexes compared to $\mathrm{Pt}(\mathrm{II})$, a reason why $\mathrm{Pd}-\mathrm{Cl}$ bond dissociates $10^{4}-10^{5}$ times faster in $\mathrm{Pd}(\mathrm{II})$ complexes [12].

Complex $\mathbf{C 4}$ was a modification of $\mathbf{C 3}$, where one $-\mathrm{Cl}$ was substituted for $-\mathrm{PPh}_{3}$ and a $-\mathrm{Br}$ introduced at position 4 on the thiophene ring. The $-\mathrm{PPh}_{3}$ group is a much better $s$ donor and $\pi$ acceptor which effectively weakens the Pt-N bond trans to itself in $\mathbf{C 4}$ through ground state trans-influence. This in turn means that electron density is not drawn from the imine region, and therefore, the imine bond in C4 retains more $\pi$ character compared to that in C3. However, the $-\mathrm{Br}$ in position 4 has minimal influence since there is no resonance donation for the nonbonding electrons. These factors resulted in the observed difference in energy for the imine bonds, $1608 \mathrm{~cm}^{-1}$ versus $1593 \mathrm{~cm}^{-1}$ for C4 and C3, respectively.

Complex $\mathbf{C} \mathbf{2}$ was a modification of $\mathbf{C} \mathbf{1}$, where a $-\mathrm{Br}$ was introduced at position 5 on the thiophene ring. At position 5, there is a possible resonance donation from the halide lone pair implying that the imine bond retains more $\pi$ character in $\mathbf{C 4}$ compared to $\mathbf{C} \mathbf{1}$, reflected in the hypsochromic shift observed in C2 $\left(1621 \mathrm{~cm}^{-1}\right.$ from $1608 \mathrm{~cm}^{-1}$ (L2)). The FTIR spectra data for the complexes are shown in Table 1.

3.2.1. ${ }^{1} H$-NMR Spectra. The azomethine protons together with the protons attached to the thiophene ring were observed and compared for the three ligands after introduction of the bromide substituent, as shown in Figure 1.

For L1, $\mathrm{H}_{\mathrm{a}}, \mathrm{H}_{\mathrm{b}}$, and $\mathrm{H}_{\mathrm{c}}$ occurred at $7.13,7.45$, and $7.65 \mathrm{ppm}$, respectively, while the azomethine proton occurred at $8.25 \mathrm{ppm}$. Upon introduction of a $\mathrm{Br}$ at position 4 (L3), the remaining protons $\mathrm{H}_{\mathrm{a}}$ and $\mathrm{H}_{\mathrm{c}}$ appeared further downfield (7.53 and $7.75 \mathrm{ppm}$, respectively), as a result of deshielding by the $\mathrm{Br}$ substituent. Similar trend is observed when the $\mathrm{Br}$ is introduced at position $5(\mathbf{L 2})$. The peaks for $\mathrm{H}_{\mathrm{a}}$ and $\mathrm{H}_{\mathrm{b}}$ now appear at 7.27 and $8.14 \mathrm{ppm}$, respectively. Together with the electronegativity of the $-\mathrm{Br}$, the protons at orthoposition to $-\mathrm{Br}$ experience steric deshielding as the hydrogen s-orbitals are disrupted from the normal spherical symmetry.

The azomethine proton for $\mathbf{L} \mathbf{1}$ appeared at $8.25 \mathrm{ppm}$. On introduction of a $\mathrm{Br}$ at position 4 (L3) and position 5 (L2) of the thiophene ring, an upfield shift of $0.10 \mathrm{ppm}$ (to $8.16 \mathrm{ppm}$, L3) and $0.11 \mathrm{ppm}$ (to $8.14 \mathrm{ppm}, \mathbf{L 2}$ ) was observed. This trend is expected because, at position 5 , there is resonance 


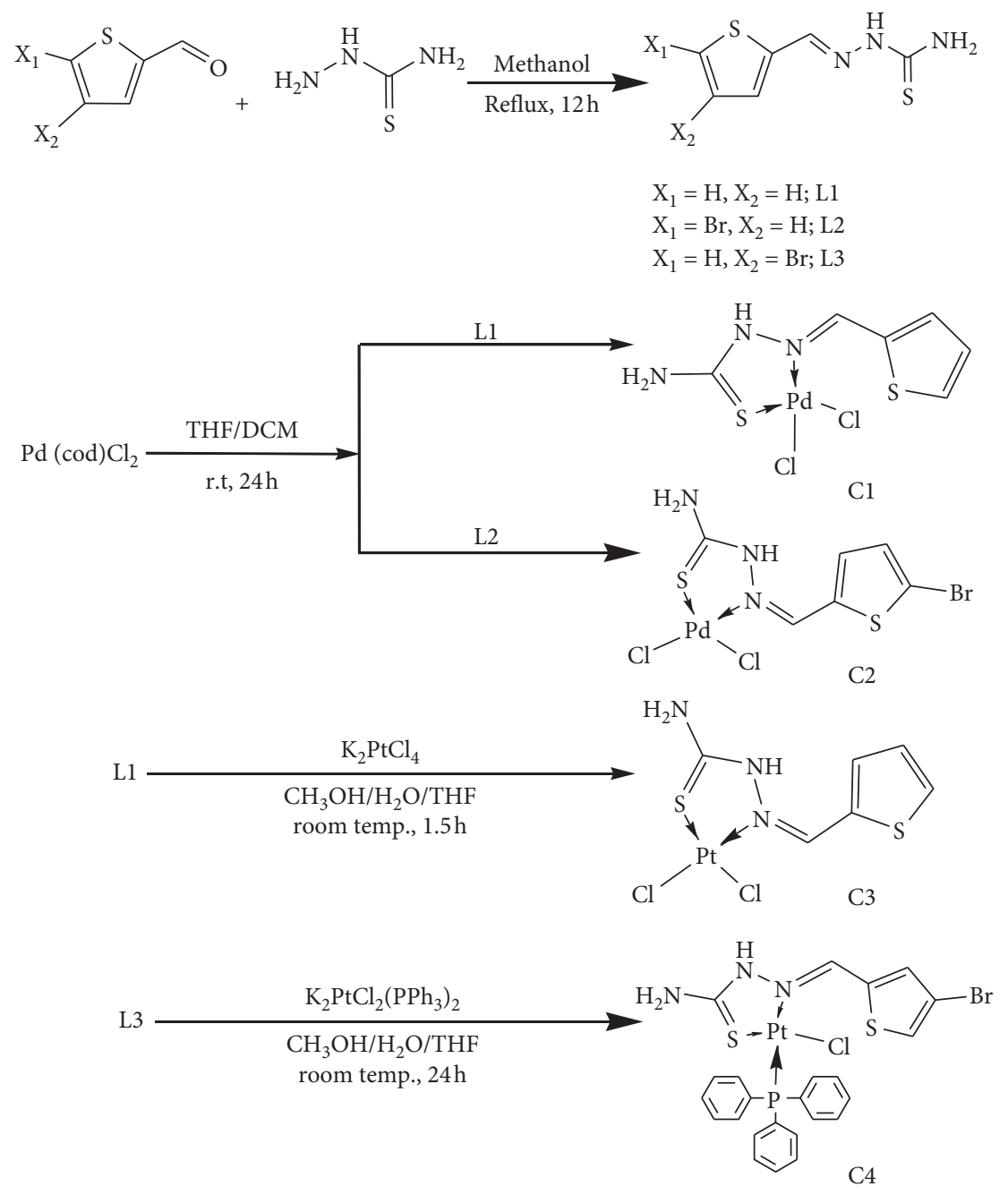

Scheme 1: Synthesis of Pd (II) and Pt (II) complexes.

Table 1: Photophysical data for ligands (L1-L3) and complexes (C1-C4).

\begin{tabular}{|c|c|c|c|c|}
\hline & $\begin{array}{c}\text { FTIR } \\
\text { Imine }(\mathrm{C}=\mathrm{N}) \\
\end{array}$ & $\begin{array}{c}{ }^{1} \mathrm{H}-\mathrm{NMR} \\
\text { Imine }(\mathrm{CH}=\mathrm{N})\end{array}$ & $\begin{array}{c}{ }^{13} \mathrm{C}-\mathrm{NMR} \\
\text { Imine }(\mathrm{C}=\mathrm{N})\end{array}$ & $\begin{array}{c}\text { Absorption }\left(\varepsilon \times 10^{4} \mathrm{LMol}^{-1} \mathrm{~cm}^{-1}\right) \\
\lambda_{\max }(\mathrm{nm}) \\
\end{array}$ \\
\hline L1 & 1611 & 8.25 & 139.09 & $340(0.53)$ \\
\hline $\mathbf{L} 2$ & 1608 & 8.14 & 141.16 & $347(0.64)$ \\
\hline L3 & 1605 & 8.16 & 140.58 & $343(0.61)$ \\
\hline $\mathrm{C} 1$ & 1619 & 8.41 & 146.04 & $364,382(1.51,1.34)$ \\
\hline $\mathrm{C} 2$ & 1621 & 7.59 & 145.02 & $371,390(1.16,1.09,0.0557)$ \\
\hline C3 & 1593 & 8.55 & 145.86 & $348,363,540(1.30,0.86,0.0087)$ \\
\hline $\mathrm{C4}$ & 1608 & 7.96 & 142.98 & $348,401,555(1.41,1.31)$ \\
\hline
\end{tabular}<smiles>Cc1cc(/C=N/NC(N)=S)sc1C</smiles>

(a)<smiles>Cc1cc(/C=N/NC(N)=S)sc1Br</smiles>

(b)<smiles>Cc1c(Br)csc1/C=N/NC(N)=S</smiles>

(c)

Figure 1: Ligands (a) L1, (b) L2, and (c) L3. 
donation of $\mathrm{Br}$ lone pair electrons; thus, the azomethine proton for $\mathbf{L} 2$ experiences a higher shielding effect and resonates further upfield compared to L3. The ${ }^{1} \mathrm{H}-\mathrm{NMR}$ spectra data are shown in Table 1 . A representative ${ }^{1} \mathrm{H}-\mathrm{NMR}$ spectrum for ligand $\mathbf{L} 3$ is shown in Figure 2.

Upon complexation, the resonance frequencies of the azomethine protons were observed and compared to those of the free ligands. Complexes $\mathbf{C} \mathbf{1}$ and $\mathbf{C} \mathbf{3}$ were compared to the parent ligand $\mathbf{L} \mathbf{1}$, where a downfield shift was observed in both complexes. The Pd(II) complex (C1) showed a lesser shift of $0.16 \mathrm{ppm}$ compared to $0.30 \mathrm{ppm}$ observed in the $\mathrm{Pt}(\mathrm{II})$ complex C3. As discussed above, this can be attributed to the higher nuclear charge of $\mathrm{Pt}(\mathrm{II})$ compared to $\mathrm{Pd}(\mathrm{II})$, which causes a higher deshielding of the azomethine region in the Pt(II) complex leading to a more downfield shift for the azomethine proton. A representative ${ }^{1} \mathrm{H}-\mathrm{NMR}$ spectrum for complex $\mathbf{C l}$ is shown in Figure 3.

Complexes $\mathbf{C} 3$ and $\mathbf{C} 4$ differed in that there was a $\mathrm{Br}$ substituent attached to the thiophene ring, and the $\mathrm{PPh}_{3}$ group coordinated to the metal center in $\mathbf{C 4}$, while no substituent was present in $\mathbf{C} 3$, and coordination to the metal was by $\mathrm{Cl}$ ligands. Considering $\mathrm{C} 4$ with a $\mathrm{Br}$ at position 4 and a $\mathrm{PPh}_{3}$ directly coordinated to the metal center, the $\mathrm{Br}$ at position 4 has minimal resonance influence to the complex, but $\mathrm{PPh}_{3}$ is both a good $s$ donor and a $\pi$ acceptor. The $s$ donation is through a hybrid orbital containing a lone pair located on phosphorus, which is enhanced by the electronrich phenyl rings attached to the phosphorus. The steric bulk of the $\mathrm{PPh}_{3}$ group and the resultant crowding around the metal center is a determinant in the rate at which the group dissociates from a metal, where the bulkier the R group, the faster the rate of dissociation [13]. These factors together with the higher trans-influence of $\mathrm{PPh}_{3}$ compared to $\mathrm{Cl}$ make $\mathbf{C 4}$ to be more shielded at the azomethine region compared to C3. This resulted in the observed difference of $0.59 \mathrm{ppm}$ between the azomethine protons of the two complexes.

Complexes $\mathbf{C} 2$ and $\mathbf{C} \mathbf{1}$ differed only on the Br substituent at position 5 of the thiophene ring of $\mathbf{C} 2$. At position 5 , the $\mathrm{Br}$ substituent has possible resonance donation to the adjacent $\pi$ system. This increases the shielding of the azomethine proton making it to resonate at a higher field region compared to that of $\mathbf{C l}$. The ${ }^{1} \mathrm{H}-\mathrm{NMR}$ spectra for the complexes are shown in Table 1.

3.2.2. ${ }^{13} \mathrm{C}$-NMR Spectra. The ${ }^{13} \mathrm{C}-\mathrm{NMR}$ spectra for the ligands were compared with those of their corresponding complexes for carbons at the imine regions. The ligand imine carbons shifts occurred at $139.24 \mathrm{ppm}, 141.07 \mathrm{ppm}$, and $140.80 \mathrm{ppm}$ for $\mathbf{L 1}, \mathbf{L} 2$, and $\mathbf{L 3}$, respectively. Introduction of a $-\mathrm{Br}$ at position 5 (L2) had an incremental effect on the chemical shift (by $1.83 \mathrm{ppm}$ ) on the imine carbon compared to the $-\mathrm{Br}$ at position 4 (L3) which caused a shift of $1.56 \mathrm{ppm}$. At position 5 , the $-\mathrm{Br}$ has a higher inductive effect on the ligand via the $\pi$ system, which deshields the imine carbon more causing it to resonate at a higher frequency (low field). The ${ }^{13} \mathrm{C}$-NMR spectra for the ligands are shown in Table 1 . A representative ${ }^{13} \mathrm{C}-\mathrm{NMR}$ spectrum for ligand L3 is shown in Figure 4.
After complexation, the shifts for the imine carbon of complexes $\mathbf{C 1}$ and $\mathbf{C 3}$ occurred further downfield (146.04 ppm and $145.86 \mathrm{ppm}$, respectively) compared to the parent ligand L1. This increase in shift by $6.95 \mathrm{ppm}$ and $5.28 \mathrm{ppm}$ is as a result of coordination to the metal as electron density is pulled away from the azomethine bond deshielding the carbon nucleus. This means that only a smaller external magnetic field is necessary to bring the nucleus into resonance, resulting in the observed higher chemical shifts in ${ }^{13} \mathrm{C}$-NMR. Similar trend is observed for complexes $\mathbf{C} 4$ and $\mathbf{C} 2$ compared to the parent ligands. A representative ${ }^{13} \mathrm{C}-\mathrm{NMR}$ spectrum for complex $\mathrm{C} 2$ is shown in Figure 5.

3.2.3. Electronic Spectra. UV-visible spectra for the compounds were recorded in DMSO at range $200-800 \mathrm{~nm}$ using quartz cells at a concentration of $1.0 \times 10^{-3} \mathrm{M}$. The results for the photophysical data are summarized in Table 1.

As shown in Table 1, a higher bathochromic shift $(7 \mathrm{~nm})$ was observed in $\mathbf{L} 2$ after introducing $\mathrm{Br}$ at position 5 of the thiophene ring than in $\mathbf{L 3}(3 \mathrm{~nm})$ with the $-\mathrm{Br}$ at position 4 . An auxochrome at position 5, as opposed to position 4, has better $p-\pi$ conjugation with the rest of the $\pi$ system from the possible resonance donation of the lone pair on - $\mathrm{Br}$. This increased conjugation led to the observed hyperchromic effect in $\mathbf{L} 2$.

The complexes had different metal centers and ligands coordinated to the metal. $\mathbf{C} \mathbf{1}$ and $\mathbf{C} 3$ differed only by the type of metal center. The absorbance for $\mathbf{C} 3$ with a Pt (II) metal center occurred at a shorter wavelength $(348 \mathrm{~nm})$ compared to C1 $(364 \mathrm{~nm})$ with a Pd(II) metal center. A possible reason for this is the higher nuclear charge of $\mathrm{Pt}(\mathrm{II})$ which draws electron density away from the $\pi$ system effectively lowering the energy of $\pi$ orbitals thereby increasing the $\Delta \mathrm{E}$ between $\pi-\pi^{*}$ levels in $\mathbf{C} 3$. $\mathbf{C} \mathbf{1}$ and $\mathbf{C 2}$ differed only by the presence of a $-\mathrm{Br}$ in position 5 of $\mathbf{C 2}$. The presence of the auxochrome increased the electron density of the $\pi$ bonding orbitals resulting in raised energy level through electronelectron repulsion, leading to the observed longer wavelength in $\mathbf{C 2}$.

C4 and $\mathbf{C} 3$ differed in that there was a - Br substituent in position 4 of the thiophene ring, and a bulky $-\mathrm{PPh}_{3}$ coordinated to the metal center of $\mathbf{C 4}$. $\mathrm{PPh}_{3}$ is a better $s$ donor- $\pi$ acceptor compared to $\mathrm{Cl}$, and the electron-rich phenyl rings impart it with better ligand to metal charge transfer properties causing the observed red shift in C4. The UV-Vis spectra for the complexes are displayed in Table 1.

In general, ligand spectra showed peaks corresponding to $\pi \longrightarrow \pi^{*}$ transitions with molar extinction coefficients of $10^{3} \mathrm{LMol}^{-1} \mathrm{~cm}^{-1}$, while the complexes exhibited an extra broad and weak absorptions at around $550-570 \mathrm{~nm}$ assigned to $d$-d transitions, with molar extinction coefficients of $10^{1}-10^{2} \mathrm{LMol}^{-1} \mathrm{~cm}^{-1}$. In contrast, the spectra for all the complexes displayed two peaks for $\mathbf{C 1}$ and $\mathbf{C 2}$ and three peaks for C3 and C4. Similar observations are reported in literature and are attributed to a combination of the ligand based $\pi-\pi^{*}$ and MLCT [(d $\left.\pi_{(\text {metal })}-\pi^{*}{ }_{\text {(ligand) }}\right]$ [14]. The UVVis spectra for complex C3 is shown in Figure 6. 


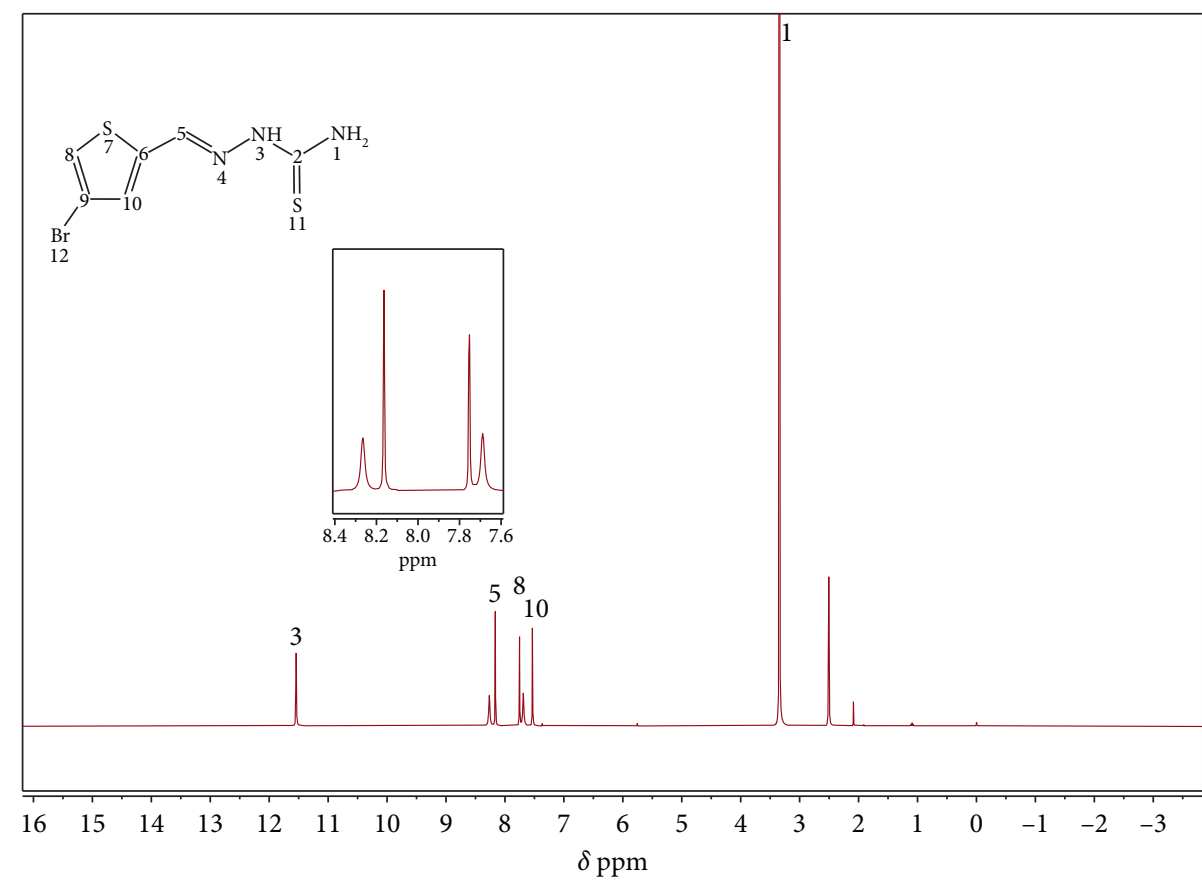

Figure 2: ${ }^{1} \mathrm{H}-\mathrm{NMR}$ spectra for ligand $\mathbf{L 3}$.

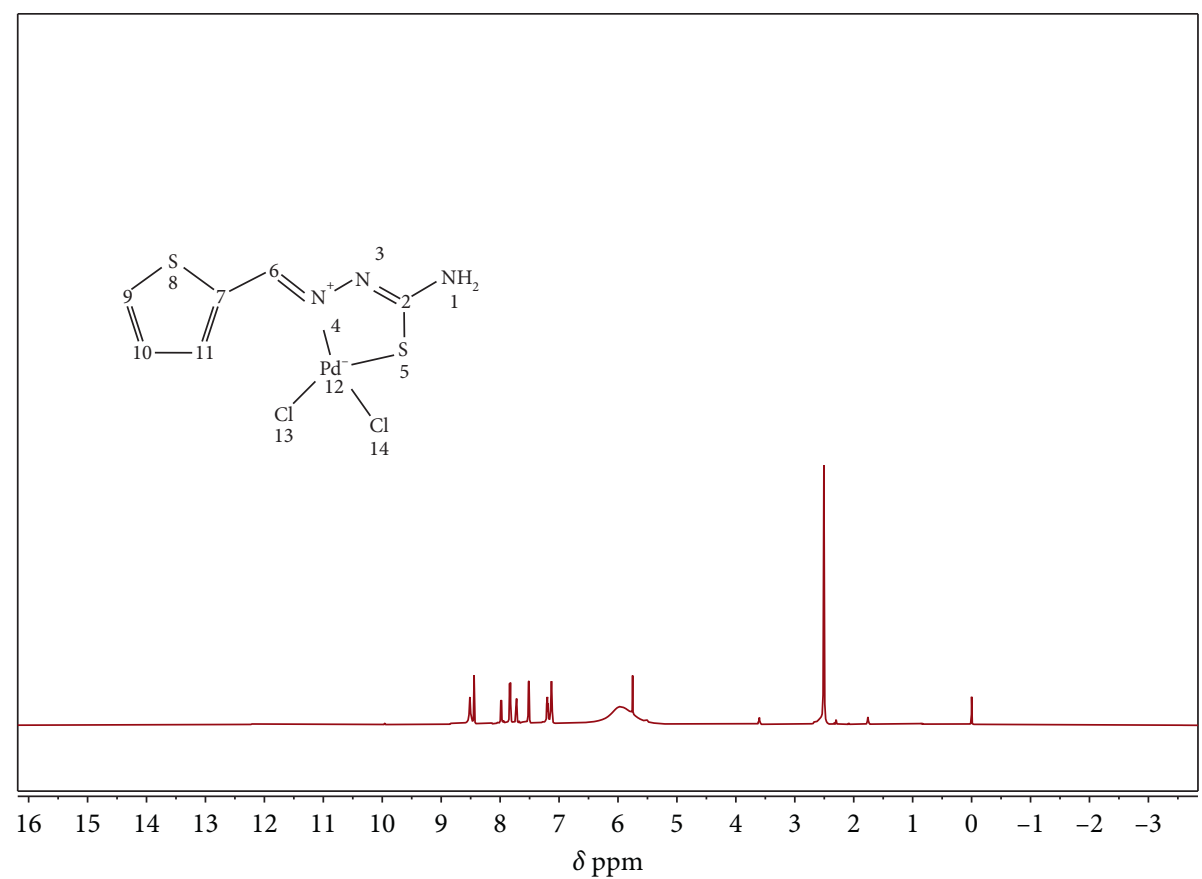

Figure 3: ${ }^{1} \mathrm{H}-\mathrm{NMR}$ spectra for complex $\mathbf{C 1}$.

3.2.4. Crystal Structure for Ligand L1. Crystals suitable for $\mathrm{X}$-ray crystallography were grown for ligand L1 by slow diffusion of hexane into a THF solution of L1. The ligand belongs to the monoclinic $\mathrm{P} 21 / n$ space system with 8 -unit molecules packed into the crystal unit. The structure data and refinement parameters are shown in Table 2. The structure showed the thiosemicarbazone existing in the thione form.
The molecular pair adopts a different conformation for each unit molecule with one molecule lying on a perfect plane but the other having a torsion angle of about $17^{\circ}$ (Figure 7(a)). The molecule is stabilized through intermolecular hydrogen bonding between the hydrogen attached to $\mathrm{N}-5$ of one molecule and thiosemicarbazide sulphur of the other molecules. Furthermore, hydrogen bonding extends towards the adjacent molecular pair, as shown in Figure 7(b). 


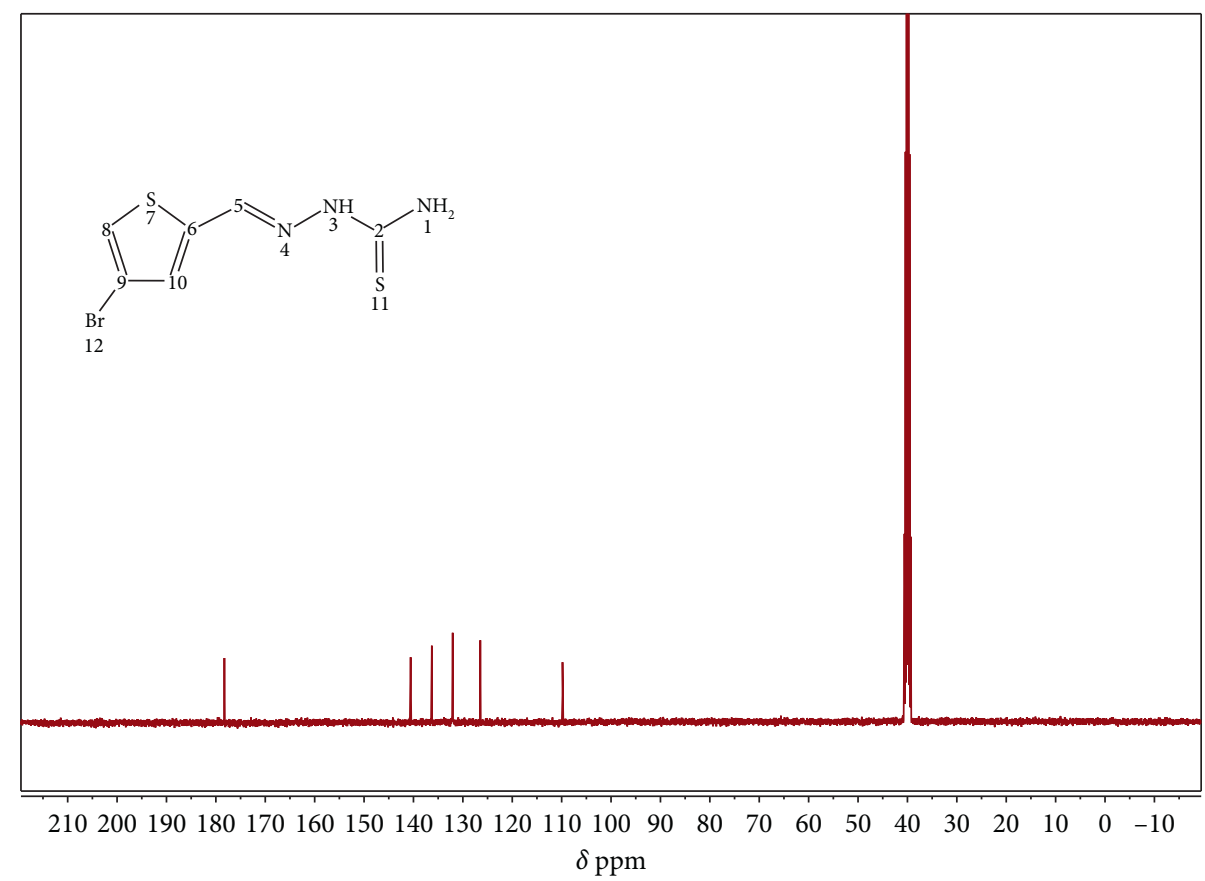

Figure $4:{ }^{13} \mathrm{C}-\mathrm{NMR}$ for $\mathbf{L} 3$.

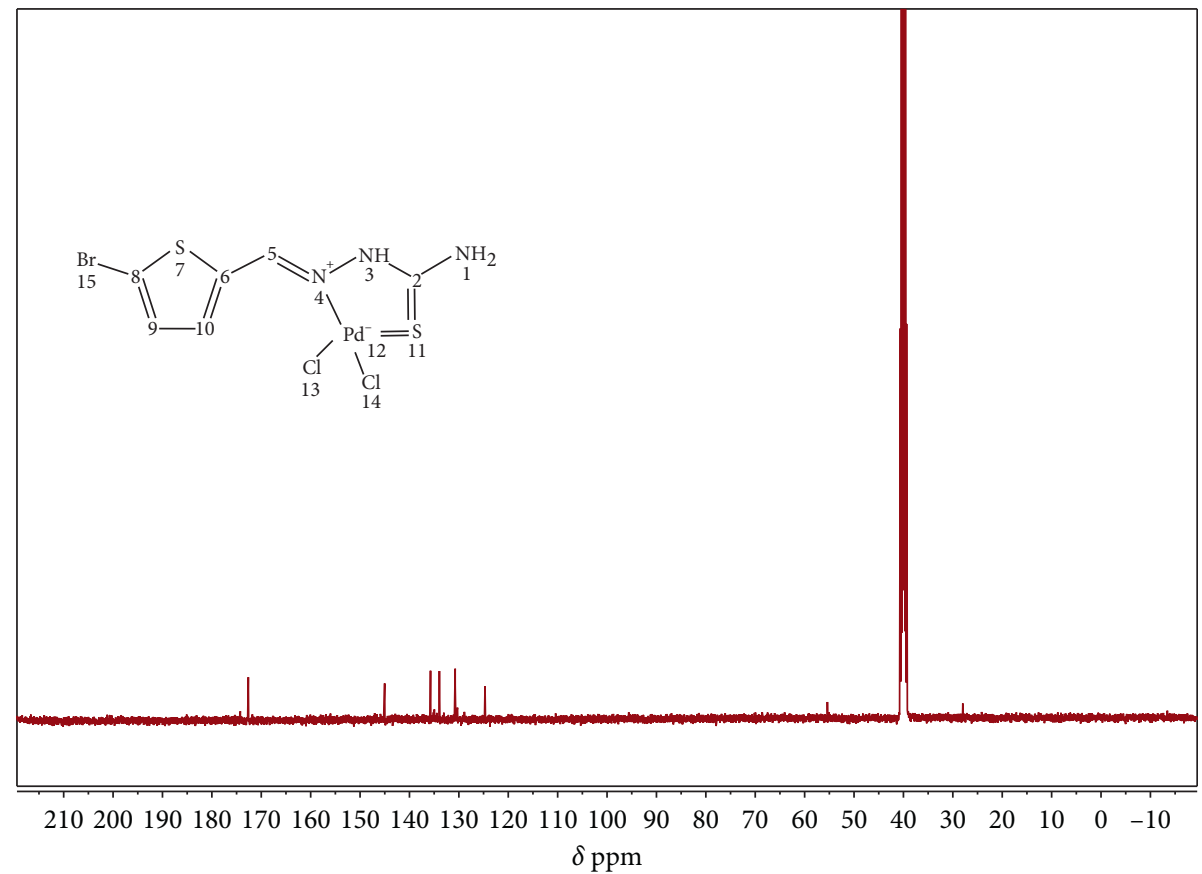

Figure 5: ${ }^{13} \mathrm{C}-\mathrm{NMR}$ for C2.

Proton scans over a $72 \mathrm{~h}$ period were conducted to establish stability in solution, as shown in Figure 8. Lack of any changes in peaks over the test period indicated that the compounds were stable in solution and therefore could be studied for bioassay.

The complexes were then subjected for bioassays to assess their anticancer activities.
3.3. Bioassays on Cytotoxicity. The main objective of this work was to evaluate thiosemicarbazone-based Pd(II) and $\mathrm{Pt}(\mathrm{II})$ complexes for possible anticancer properties. The motivation behind this study was two-fold. First, the sterically bulky substituents around the metal center are a strategy appearing in literature for prevention of axial approach to the metal atom from the $z^{2}$-direction. This hinders 


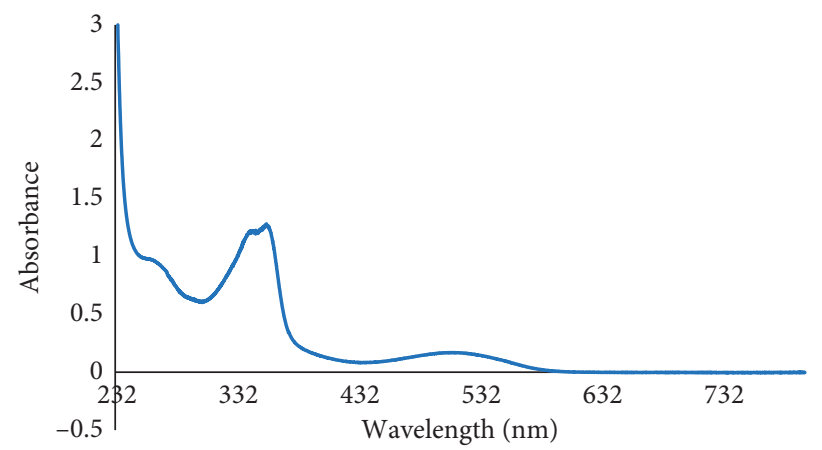

Figure 6: UV-Vis spectra for complex C3.

Table 2: Crystal data for $\mathbf{L} 1$.

\begin{tabular}{|c|c|}
\hline Chemical formula & $\mathrm{C}_{6} \mathrm{H}_{7} \mathrm{~N}_{3} \mathrm{~S}_{2}$ \\
\hline $\begin{array}{l}\text { Mr } \\
\text { Crystal system, space group } \\
\text { Temperature }(\mathrm{K}) \\
\mathrm{a}, \mathrm{b}, \mathrm{c}(\AA) \\
\beta\left({ }^{\circ}\right) \\
V\left(\AA^{3}\right) \\
Z \\
\text { Radiation type } \\
\mu\left(\mathrm{mm}^{-1}\right) \\
\text { Crystal size }(\mathrm{mm}) \\
\end{array}$ & $\begin{array}{c}185.27 \\
\text { Monoclinic, P21/n } \\
100 \\
13.4381(2), 5.7728(1), 21.2683(4) \\
96.302(1) \\
1639.93(5) \\
8 \\
\text { Cu K } \alpha \\
5.37 \\
0.37 \times 0.23 \times 0.19 \\
\end{array}$ \\
\hline $\begin{array}{l}\text { Data collection } \\
\text { Diffractometer } \\
T_{\min }, T_{\max } \\
\text { No. of measured, independent, and observed }(\mathrm{I}>2 \sigma(\mathrm{I})) \text { reflections } \\
\mathrm{R} \text { int } \\
(\sin \theta / \lambda) \max \left(\AA^{-1}\right)\end{array}$ & $\begin{array}{c}\text { Bruker SMART CCD Apex-II area-detector } \\
0.272,0.496 \\
21136,2897,2744 \\
0.041 \\
0.596\end{array}$ \\
\hline $\begin{array}{l}\text { Refinement } \\
\mathrm{R}\left[F^{2}>2 \sigma\left(F^{2}\right)\right], w \mathrm{R}\left(F^{2}\right), \mathrm{S} \\
\text { No. of reflections } \\
\text { No. of parameters } \\
\mathrm{H} \text {-atom treatment } \\
\Delta \rho_{\max }, \Delta \rho_{\min }\left(\mathrm{e} \AA^{-3}\right)\end{array}$ & $\begin{array}{c}0.026,0.067,1.04 \\
2897 \\
200 \\
\text { H-atom parameters constrained } \\
0.37,-0.27\end{array}$ \\
\hline
\end{tabular}
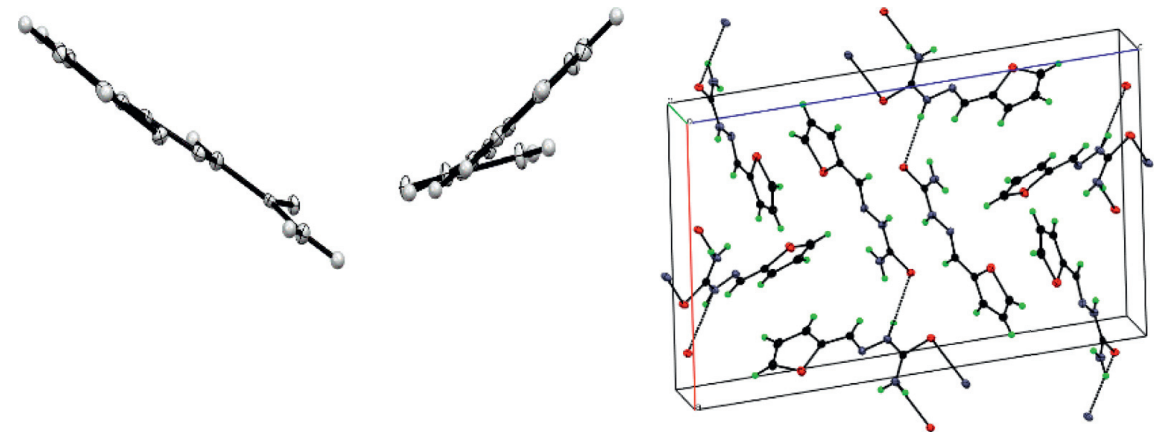

(a)

(b)

FIgURE 7: (a) ORTEP view for the molecular pair for ligand L1 showing the torsion in one molecule; (b) the crystal packing and H-bonding. 

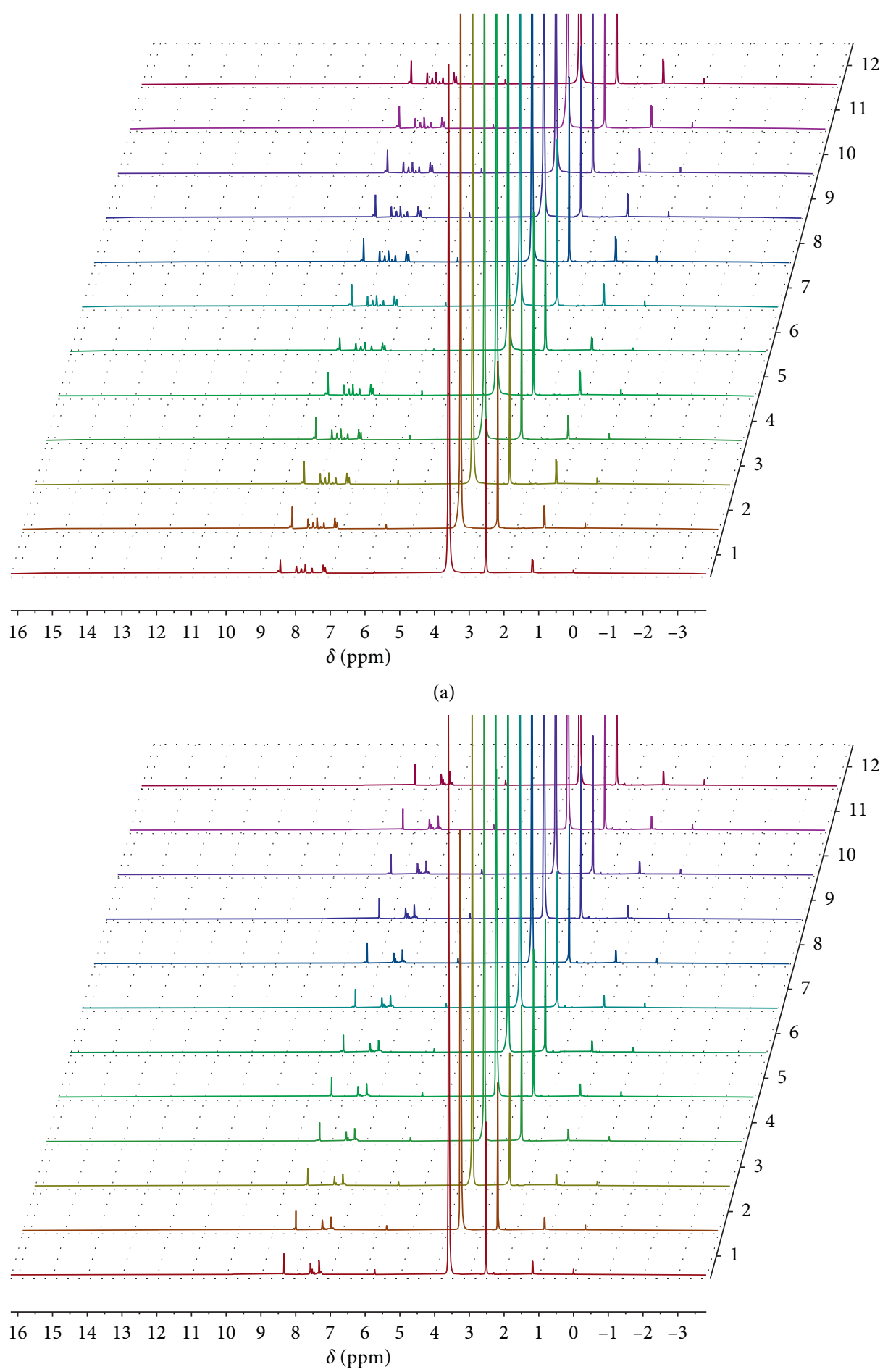

(b)

Figure 8: Continued. 




(c)

Figure 8: ${ }^{\mathrm{I}} \mathrm{H}-\mathrm{NMR}$ scans for (a) $\mathbf{C 1}$, (b) $\mathbf{C 2}$, and (c) $\mathbf{C 4}$ at $6 \mathrm{~h}$ intervals for $72 \mathrm{~h}$ in the presence of $\mathrm{D}_{2} \mathrm{O}$.

the formation of a trigonal bipyramid (TBP) intermediate which would lead to a ligand substitution [15] and thereby lead to high binding selectivity to DNA in vitro and in vivo [16]

Secondly, it has been shown that bidentate chelation plays a significant role in preventing trans-labilization and unwanted dislodgment of ligands in vivo [17, 18]. Preliminary results with the free ligands did not show any substantial activity either as anticancer agents, and therefore, the detected activity could be accredited to the complexed forms.

The anticancer activity was calculated according to the following equation:

$$
\begin{aligned}
\% \text { cell viability }= & \left(\frac{\text { average absorbances of treated cells }}{\text { average absorbances of control }}\right) \\
& \times 100 \% .
\end{aligned}
$$

The results obtained against a control under similar test conditions with no test compound added are shown in Figure 9.

Structure-activity correlations were drawn on the different trends in cytotoxicity of these complexes. Complex $\mathbf{C l}$ was similar to $\mathbf{C} 2$ differing only by a $-\mathrm{Br}$ substituent on position 5 of the thiophene moiety of $\mathbf{C 2}$. Comparing the results for these two complexes, the introduction of the $-\mathrm{Br}(\mathrm{C} 2)$ resulted in remarkable difference in activity, where cell viability in all cell lines Caco-2 (8\%), HepG2 (5\%), HeLa (38\%), MCF-7 (6\%), MCF$12 \mathrm{~A}(5 \%)$, and PC-3 (49\%) increased remarkably. The difference in the results for $\mathbf{C} \mathbf{1}$ and $\mathbf{C} \mathbf{2}$ could be attributed to the presence of $-\mathrm{Br}$ in $\mathbf{C} 2$ which decreased the electron density around the metal center. This caused the - $\mathrm{Cl}$ ligands to be held more firmly, which in turn decreased the rate of - $\mathrm{Cl}$ substitution reducing the cytotoxicity of C2. Similar observations are reported in literature where it is observed that an increase in donor properties of the coordinated groups directly leads to increased cytotoxicity for Pd drugs [19].

Complexes $\mathbf{C} \mathbf{1}$ and $\mathbf{C} 3$ had similar structures differing only by the metal center, $\mathrm{Pd}(\mathrm{II})$ for $\mathbf{C 1}$ and $\mathrm{Pt}(\mathrm{II})$ for $\mathbf{C} \mathbf{3}$. Complex $\mathbf{C 1}$ was found to be more cytotoxic than $\mathbf{C} 3$ in all the tested cells. Since Pd(II) has a lower nuclear charge compared to Pt(II), the ligands are less strongly held in C1. The smaller spatial size of 4d-orbitals in Pd (II) compared to $5 \mathrm{~d}$-orbitals in Pt (II) also led to more steric crowding in the Pd (II) centre which probably resulted in higher rates of ligand substitution, raising the cytotoxicity in $\mathrm{C}$.

The observed higher cytotoxicity in $\mathbf{C 4}$ in comparison to $\mathbf{C} 3$ could be attributed to the steric crowding effects of the bulky $\mathrm{PPh}_{3}$ group in $\mathbf{C} 4$ since the steric bulk of a $\mathrm{PR}_{3}$ group and the resultant crowding around the metal center is a determinant in the rate at which the group dissociates from the metal. Tolman [13] working on nickel complexes made similar observations where steric hindrance played a bigger role than electronic effects in influencing the rate of attaining equilibrium in a number of phosphorus ligands on nickel(0) [13]. The expected higher ligand dissociation determined the observed higher cytotoxicity for C4 compared to $\mathbf{C} 3$ with a $\mathrm{Cl}$ group. The plain ligands did not show any substantial activity at the tested dose (data not shown) compared to their corresponding complexes, and therefore, the reduced cell proliferation shown could be accredited to the complex compounds. 




- Control

- C1

(a)

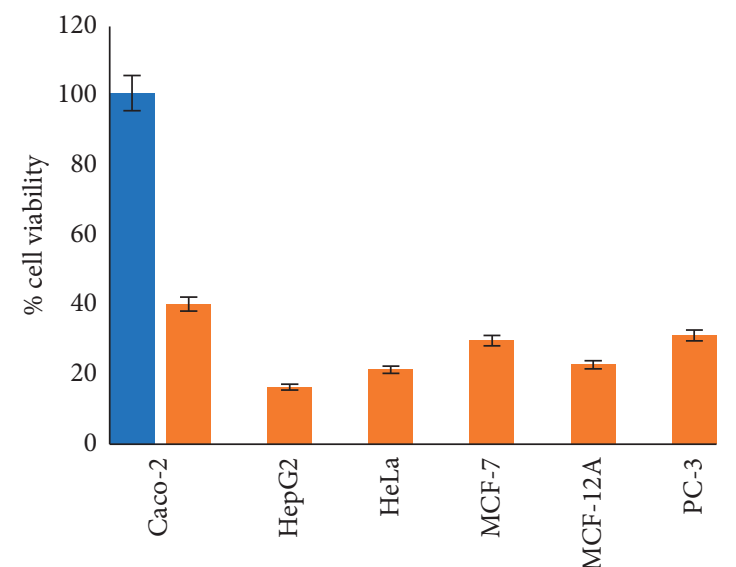

Control

C3



Control

C2

(b)

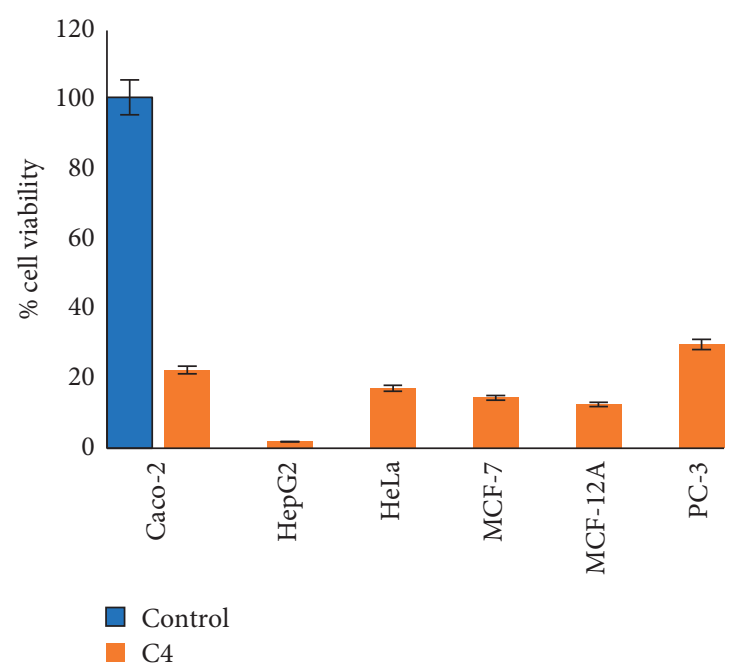

(d)

FIGURE 9: Percent cell viability for the different compounds (C1-C4) after 24 h of treatment assessed by the colorimetric MTT assay: (a) C1; (b) $\mathrm{C} 2$; (c) $\mathrm{C} 3$; (d) $\mathrm{C} 4$.

TABle 3: The $\mathrm{IC}_{50}$ values for ligands and complexes C1-C4.

\begin{tabular}{lccccc}
\hline & & \multicolumn{4}{c}{ Complex $(\mu \mathrm{M})$} \\
& C1 & C2 & C3 & C4 & Ligands \\
\hline Caco-2 & $14.71 \pm 0.016$ & $43.08 \pm 0.001$ & $17.52 \pm 0.005$ & $31.14 \pm 0.002$ & $>100(\mathrm{~L} 1-\mathrm{L} 4)$ \\
MCF-7 & $1.973 \pm 0.048$ & $59.56 \pm 0.010$ & $12.52 \pm 0.011$ & $70.09 \pm 0.006$ & $>100$ (L1-L4) \\
HeLa & $16.65 \pm 0.051$ & $72.25 \pm 0.003$ & $19.2 \pm 0.003$ & $46.25 \pm 0.011$ & $>100$ (L1-L4) \\
HepG2 & $14.64 \pm 0.037$ & $94.34 \pm 0.003$ & $29 \pm 0.003$ & $48.03 \pm 0.006$ & $>100(\mathrm{~L} 1-\mathrm{L} 4)$ \\
PC-3 & $14.05 \pm 0.042$ & $>100$ & $6.98 \pm 0.008$ & $12.63 \pm 0.036$ & $>100(\mathrm{~L} 1-\mathrm{L} 4)$ \\
\hline
\end{tabular}

The $\mathrm{IC}_{50}$ values for the complexes are tabulated in Table 3.

3.4. DNA-Binding Studies. Spectroscopy is widely used in the study of binding modes for metal complexes by observing the alterations that appear in the $\lambda_{\max }$ absorption values of $\pi-\pi^{*}$ intraligand transitions, ligand $\longrightarrow$ metal charge transfers, or on the $d$ - $d$ transitions, as the DNA concentration is serially increased to a solution of a metal complex. Binding modes are then inferred from the spectra, whereby an intercalative mode results in a hypochromic shift and bathochromic shift or hypsochromism. Intercalation is as a result of overlap of $\pi^{*}$ antibonding orbitals of the ligands bound to the complex with $\pi$ bonding orbitals of the DNA base pairs. This decreases the probable transitions, and the effect is observed as 


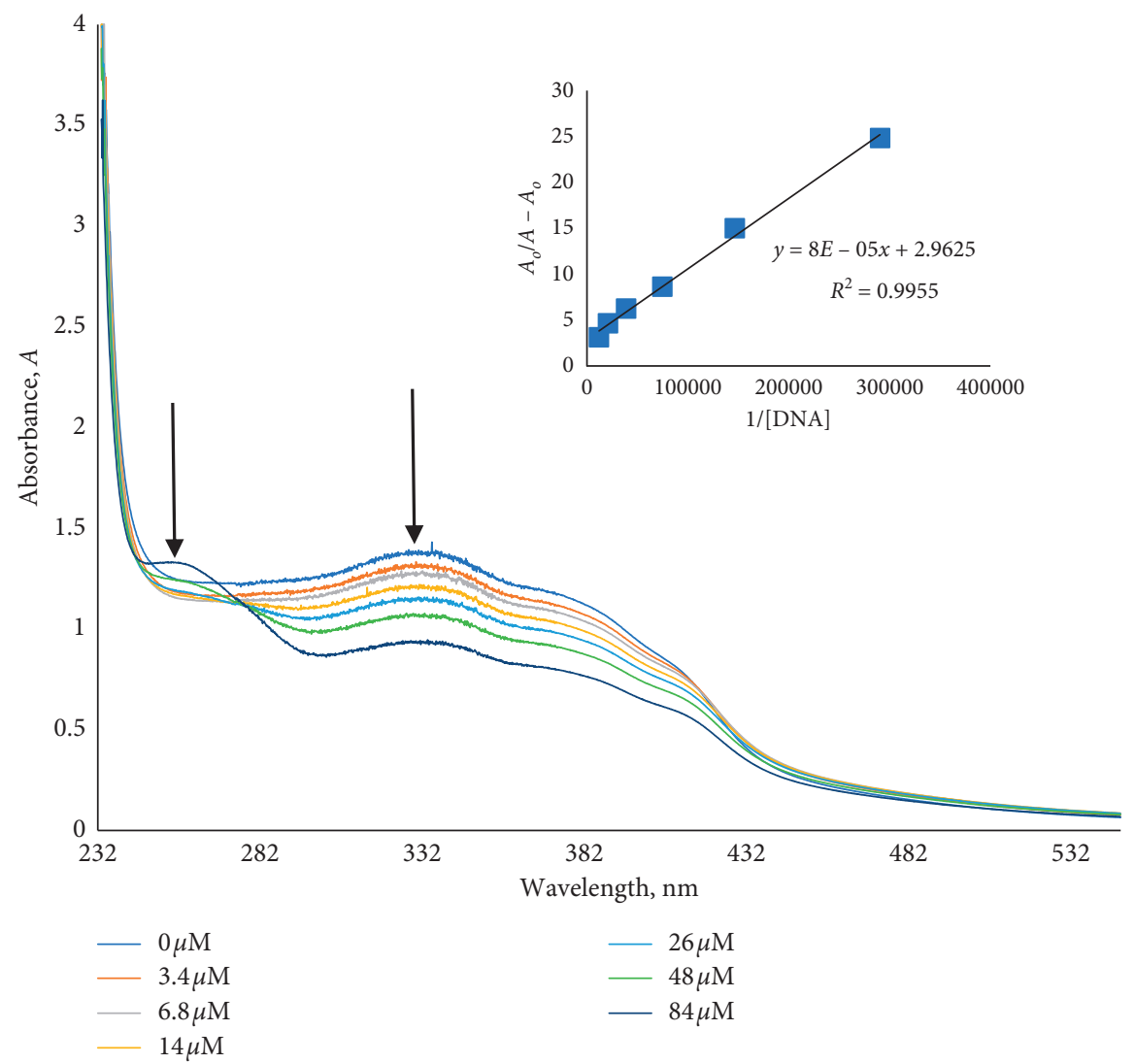

Figure 10: UV-visible absorption spectra for the $\mathrm{Cl}$ at $18 \mu \mathrm{M}$ without CT-DNA and with serial addition of DNA. Inset is the Benesi-Hildebrand plots for the determination of binding constant.

hypochromic response [20]. On the contrary, a hyperchromic shift suggests electrostatic mode of binding. The spectral shift in the metal complex absorption is correlated to the binding strength from which the kinetics can then be determined [21].

Observations on the changes occurring in the UV-Vis spectra of a compound during serial additions of DNA is an accepted procedure in studying the binding modes and kinetics of DNA-complex interactions [22]. In this study, we used calf thymus-DNA (CT-DNA) prepared in $10 \mathrm{mM}$ Tris- $\mathrm{HCl}$ buffer at $\mathrm{pH}$ 7.29. The DNA concentration was calculated from the $\lambda_{\max }$ of $260 \mathrm{~nm}$ using the molar absorptivity of the CT-DNA and $\varepsilon=6600 \mathrm{M}^{-1}$. The ratio of the absorbance $\left(\mathrm{A}_{260} / \mathrm{A}_{280}\right)$ was found to be 1.918 which assured that DNA was free of protein [23].

Serial concentrations of calf thymus DNA (CT-DNA) were titrated to a fixed concentration of the complexes in the cuvette and scanned from $200-800 \mathrm{~nm}$. The mixture was allowed to incubate for 5 minutes prior to taking UV-Vis measurements. With continued addition of DNA, the peaks of interest eventually decreased up to a point where they disappeared, and at the same time, there appeared a peak at $260 \mathrm{~nm}$. This clearly showed that all the complex had been bound to DNA and further additions resulted in excess free DNA in the mixture which was indicated by the appearance of a characteristic DNA peak at $260 \mathrm{~nm}$.

The binding kinetics for the complex-DNA interaction was then determined by the intrinsic binding constant, $K_{\mathrm{b}}$, by plots of the Benesi-Hildebrand equation [24] and shown as follows:

$$
\frac{A_{O}}{A-A_{O}}=\frac{\varepsilon_{G}}{\varepsilon_{H-G}}+\frac{\varepsilon_{G}}{\varepsilon_{H-G}} \frac{1}{K_{b}[\mathrm{DNA}]}
$$

where $A_{o}$ and $A$ are the absorbances of the blank sample without DNA and absorbance of complex DNA after addition of serial concentrations of DNA, respectively, while $\varepsilon_{G}$ and $\varepsilon_{H-G}$ are the molar extinction coefficients of complex only and complex DNA, respectively. The binding constant is determined by plotting $A_{o} /\left(A-A_{o}\right)$ vs $1 /[\mathrm{DNA}]$ to give a straight line graph. The equation of the straight line gives the slope and intercept where the $K_{\mathrm{b}}$ value was calculated from the ratio of the intercept to the slope. The strength of the interaction is reflected by the value of the binding constant.

From the binding constant values, Gibbs free energy changes, $\Delta G$, for the complex DNA interactions were calculated using the following equation:

$$
\Delta G=-\mathrm{RT} \ln K_{\mathrm{b}} \mathrm{kJmol}^{-1},
$$

where $\mathrm{R}$ is the gas constant and $\mathrm{T}$ is the absolute temperature.

The absorption spectra of the interaction of CT-DNA with the complexes together with the Benesi-Hildebrand plots are shown in Figures 10-13.

All the complexes exhibited hypochromic shifts at $\lambda_{\max }$. The hypochromism is probably the result of intercalative mode of binding as a result of the overlap of $\pi^{*}$ antibonding orbitals of the ligands bound to the complex, with $\pi$ bonding 




Figure 11: UV-visible absorption spectra for the C2 at $18 \mu \mathrm{M}$ without CT-DNA and with serial addition of DNA. Inset is the Benesi-Hildebrand plots for the determination of binding constant.

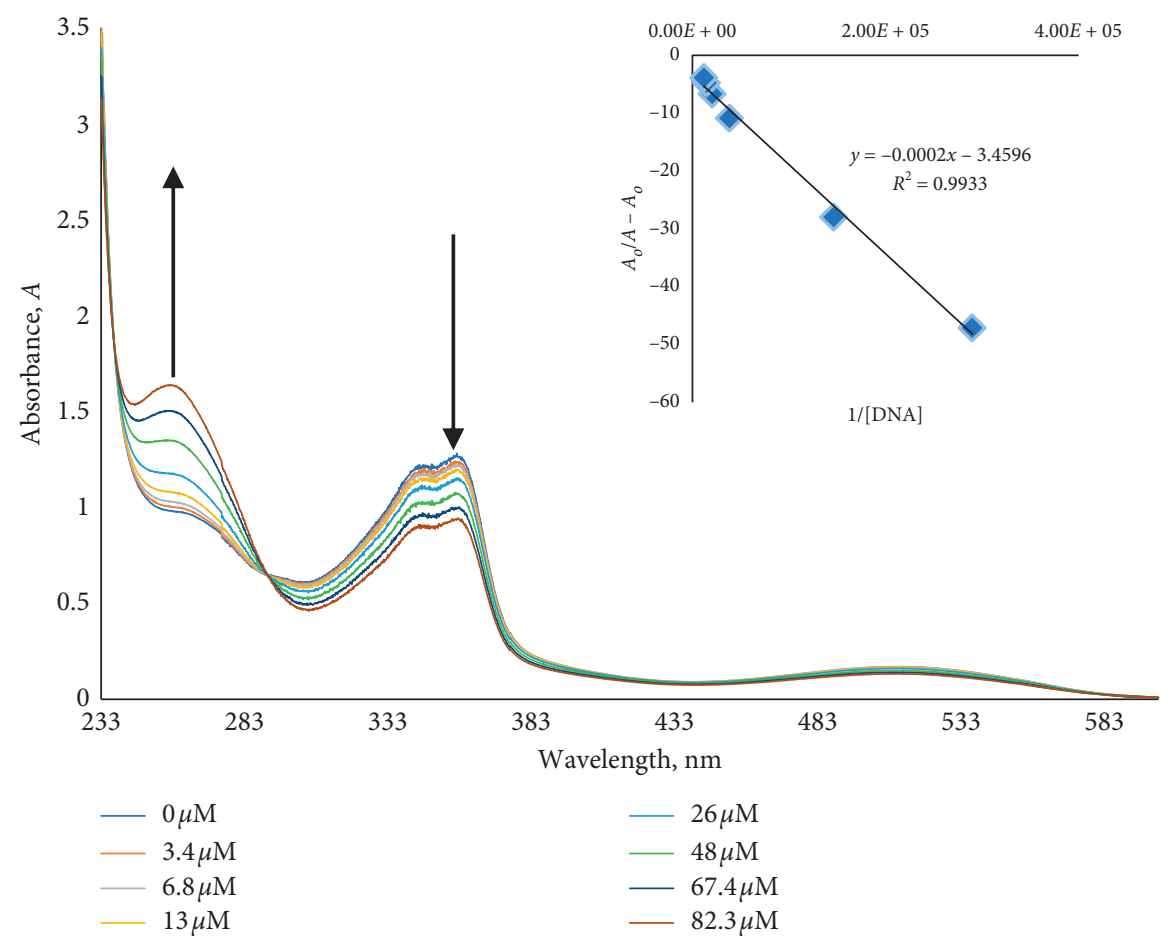

FIGURE 12: UV-visible absorption spectra for the $\mathbf{C} 3$ at $18 \mu \mathrm{M}$ without CT-DNA and with serial addition of DNA. Inset is the Benesi-Hildebrand plots for the determination of binding constant.

orbitals of the DNA base pairs [25]. This decreases the probable transitions, and the effect is observed as a hypochromic shift [20].
Furthermore, distinct isosbestic points appeared at $283 \mathrm{~nm}$ in the spectra of C2 and C4 and $292 \mathrm{~nm}$ for C3. This is as a result of equilibrium between bound and free 


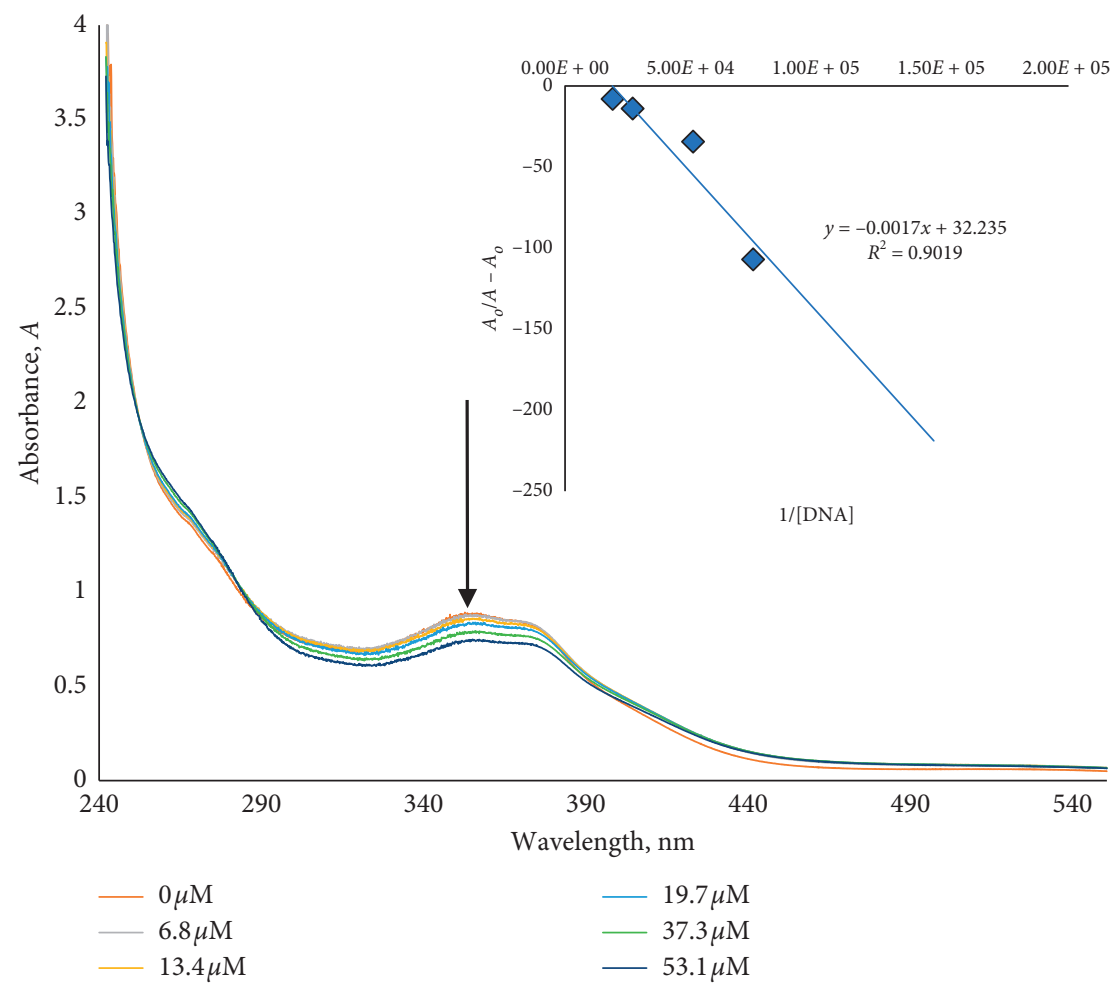

Figure 13: UV-visible absorption spectra for the $\mathbf{C 4}$ at $18 \mu \mathrm{M}$ without CT-DNA and with serial addition of DNA. Inset is the Benesi-Hildebrand plots for the determination of binding constant.

TABLE 4: Comparison of binding constants $\left(K_{\mathrm{b}}\right)$ and Gibbs free energy values for the complexes-DNA interactions derived from UV spectrophotometric data at $\mathrm{pH} 7.21$ with other reported intercalators.

\begin{tabular}{|c|c|c|c|c|}
\hline Complex & Mode of binding & Binding constant, $K_{\mathrm{b}}\left(\mathrm{M}^{-1}\right)$ & Gibbs free energy, $\Delta G\left(\mathrm{~kJ} \mathrm{~mol}^{-1}\right)$ & References \\
\hline C1 & Intercalative & $3.7031 \times 10^{4}$ & -26.03 & $\mathrm{CW}$ \\
\hline $\mathrm{C} 2$ & Intercalative & $3.403 \times 10^{3}$ & -20.15 & $\mathrm{CW}$ \\
\hline $\mathrm{C} 3$ & Intercalative & $1.7298 \times 10^{4}$ & -24.18 & $\mathrm{CW}$ \\
\hline $\mathrm{C4}$ & Intercalative & $1.8962 \times 10^{4}$ & -24.04 & $\mathrm{CW}$ \\
\hline Ethidium bromide & Intercalative & $1.4 \times 10^{6}$ & -35.06 & [27] \\
\hline Lumazine & Intercalative & $1.74 \times 10^{4}$ & -24.19 & [28] \\
\hline Epirubicin & Intercalative & $3.4 \times 10^{4}$ & -25.85 & [29] \\
\hline Proflavine & Intercalative & $2.32 \times 10^{4}$ & -24.90 & [29] \\
\hline
\end{tabular}

$\mathrm{CW}=$ current work.

form of DNA and indicates that there are no other species in the mixture [26]. Binding constant and Gibbs free energy values were then evaluated and compared to those of common DNA intercalators, as shown in Table 4.

Complex $\mathbf{C l}$ showed higher values compared to those of the known DNA intercalators lumazine, epirubicin, and proflavine, indicating a strong binding between these complexes and DNA. Complex C3 showed a lower binding constant probably due to the presence of the Br substituent. Since intercalation generally arises from the overlap of $\pi^{*}$-orbitals of intercalator with the $\pi$-orbitals DNA base pairs [30], the presence of an electronegative substituent conjugated to the $\pi$-system of an intercalator will remove electron density, thereby reducing the reactivity of the system. This may have contributed to the low binding profile of $\mathbf{C} 2$.

As shown in Table 4 , all the $\Delta \mathrm{G}$ values were negative, an indication of the spontaneity of interaction during the complex-DNA formation process [28].

\section{Conclusion}

This work produced new complexes of $\mathrm{Pd}(\mathrm{II})$ and $\mathrm{Pt}(\mathrm{II})$ with insights into tuning the physical-chemical properties and the resultant biological effects. Synthesis, isolation, and purification were all performed under mild laboratory conditions. The suggested structures were confirmed by elemental microanalysis and X-ray crystallography for one of the ligands. 
Binding profiles with DNA were studied using CT-DNA and UV-Vis spectroscopy, where they exhibited hypochromic shifts at $\lambda_{\max }$ which indicated an intercalative binding mode. Furthermore, the intrinsic DNA-binding constants, $k_{\mathrm{b}},\left(\mathrm{M}^{-1}\right)$ of $3.7031 \times 10^{4}(\mathrm{C1}), 1.7298 \times 10^{4}(\mathrm{C} 3)$, and $1.8962 \times 10^{4}(\mathbf{C 4})$ and Gibbs free energy $\left(\Delta G \mathrm{~kJ} \mathrm{~mol}^{-1}\right)$ values ranging from 24.04 to 26.03 are compared to some of the available well-known intercalators further suggesting this mode of binding. Anticancer tests against selected cancer cells in vitro showed that their activities correlated with their corresponding structures, where the different ligands around the metal center effected different rates of ligand substitution, which reflected on the observed cytotoxicity profiles. This was most notable on $\mathbf{C 2}$, which was a modification of $\mathbf{C 1}$ after introduction of $-\mathrm{Br}$ to position 5 of thiophene ring. This caused a remarkable increase in cell viability from $11 \%$ to $48 \%$ in HeLa cells and $28 \%$ to $78 \%$ in PC-3 cells and a difference of $37 \%$ and $50 \%$, respectively.

\section{Data Availability}

The data used to support these findings, i.e., FTIR peaks, ${ }^{1} \mathrm{H}$ NMR peaks, ${ }^{13} \mathrm{C}-\mathrm{NMR}$ peaks, and UV-Vis peaks, for all the compounds together with the calibration curve used to determine the CT-DNA concentration are included within the supplementary information file which has been attached as a separate PDF document. The figures are arranged as follows: (1) FTIR spectra; Figures ESI 1-7. (2) ${ }^{1} \mathrm{H}-\mathrm{NMR}$ spectra; Figures ESI 8-12. (3) ${ }^{13} \mathrm{C}-\mathrm{NMR}$ spectra; Figures ESI 13-17. (4) UV/Vis spectra; Figures ESI 18-23. (5) Calibration curve for determination of DNA concentration; Figure ESI 24. (6) CIF file for L1. The crystallographic structure for ligand $\mathrm{L} 1$ has been deposited with Cambridge Crystallographic Data Centre, CCDC 1885726. A Copy of this data may be found from CCDC, 12 Union Road, Cambridge, CB2 1EZ, UK (fax: $+44-1223-336033$ or by e-mailing deposit@ccdc.cam.ac.uk or going to the website http://www.ccdc.cam.ac.uk).

\section{Conflicts of Interest}

The authors declare that they have no conflicts of interest.

\section{Acknowledgments}

The authors acknowledge the support of the International Science Program (ISP) under KEN-01 Project for the funding and NRF, South Africa. The authors thank the Department of Chemistry, University of Nairobi, for support and guidance in this work and the Department of Chemistry and the Department of Biotechnology, University of the Western Cape (UWC), South Africa, where most of this work was carried out.

\section{Supplementary Materials}

Figures of (1) FTIR spectral data, (2) ${ }^{1} \mathrm{H}$-NMR spectra, (3) ${ }^{13} \mathrm{C}-\mathrm{NMR}$ spectra, (4) UV-Vis spectra, and (5) crystal CIF file for ligand L1. (Supplementary Materials)

\section{References}

[1] J. Ferlay, M. Colombet, I. Soerjomataram et al., "Estimating the global cancer incidence and mortality in 2018: GLOBOCAN sources and methods," International Journal of Cancer, vol. 144, no. 8, pp. 1941-1953, 2019.

[2] Y. Dai, J. Su, K. Wu et al., "Multifunctional thermosensitive liposomes based on natural phase-change material: near-infrared light-triggered drug release and multimodal imagingguided cancer combination therapy," ACS Applied Materials \& Interfaces, vol. 11, no. 11, pp. 10540-10553, 2019.

[3] J. Galon and D. Bruni, "Approaches to treat immune hot, altered and cold tumours with combination immunotherapies," Nature Reviews Drug Discovery, vol. 18, no. 3, pp. 197-218, 2019.

[4] R. S. Riley, C. H. June, R. Langer, and M. J. Mitchell, "Delivery technologies for cancer immunotherapy," Nature Reviews Drug Discovery, vol. 18, no. 3, pp. 175-196, 2019.

[5] E. M. Bavin, R. J. W. Rees, J. M. Robson, M. Seiler, D. E. Seymour, and D. Suddaby, "The tuberculostatic activity of some thiosemicarbazones," Journal of Pharmacy and Pharmacology, vol. 3, no. 1, p. 46, 1951.

[6] G. A. Kune, "To-day's drugs: methisazone," British Medical Journal, vol. 2, no. 5409, p. 621, 1964.

[7] A. C. Sartorelli and B. A. Booth, "Inhibition of the growth of sarcoma 180 ascites cells by combinations of inhibitors of nucleic acid biosynthesis and the cupric chelate of kethoxal bis-(thiosemicarbazone)," Cancer Research, vol. 27, no. 9, pp. 1614-1619, 1967.

[8] R. A. Finch, M.-C. Liu, A. H. Cory, J. G. Cory, and A. C. Sartorelli, "Triapine (3-aminopyridine-2-carboxaldehyde thiosemicarbazone; 3-AP): an inhibitor of ribonucleotide reductase with antineoplastic activity," Advances in Enzyme Regulation, vol. 39, no. 1, pp. 3-12, 1999.

[9] P. A. Channar, A. Saeed, F. A. Larik et al., "Synthesis, computational studies and enzyme inhibitory kinetics of substituted methyl [2-(4-dimethylamino-benzylidene)hydrazono)-4-oxo-thiazolidin-5-ylidene]acetates as mushroom tyrosinase inhibitors," Bioorganic \& Medicinal Chemistry, vol. 25, no. 21, pp. 5929-5938, 2017.

[10] G. M. Sheldrick, "Crystal structure refinement withSHELXL," Acta Crystallographica Section C Structural Chemistry, vol. 71, no. 1, pp. 3-8, 2015.

[11] L. J. Farrugia, "WinGX and ORTEP for windows: an update," Journal of Applied Crystallography, vol. 45, no. 4, pp. 849-854, 2012.

[12] M. D. Coskun, F. Ari, A. Y. Oral et al., "Promising anti-growth effects of palladium (II) saccharinate complex of terpyridine by inducing apoptosis on transformed fibroblasts in vitro," Bioorganic \& Medicinal Chemistry, vol. 21, no. 15, pp. 4698-4705, 2013.

[13] C. A. Tolman, "Phosphorus ligand exchange equilibriums on zerovalent nickel. Dominant role for steric effects," Journal of the American Chemical Society, vol. 92, no. 10, pp. 2956-2965, 1970.

[14] Ö. Şahin, Ü. Ö. Özdemir, N. Seferoğlu et al., “A highly selective and sensitive chemosensor derived coumarin-thiazole for colorimetric and fluorimetric detection of $\mathrm{CN}-$ ion in DMSO and aqueous solution: synthesis, sensing ability, Pd (II)/Pt (II) complexes and theoretical studies," Tetrahedron, vol. 72, no. 39, pp. 5843-5852, 2016.

[15] A. C. G. Hotze, Y. Chen, T. W. Hambley et al., "cis[PtCl2(NH3)\{2-(2-hydroxyethyl)pyridine $\}$-an analogue of the anticancer drug AMD473: unusual hydrolysis rates and 
pKa values for the diaqua adduct," European Journal of Inorganic Chemistry, vol. 2002, no. 5, pp. 1035-1039, 2002.

[16] E. Ulukaya, F. Ari, K. Dimas, E. I. Ikitimur, E. Guney, and V. T. Yilmaz, "Anti-cancer activity of a novel palladium (II) complex on human breast cancer cells in vitro and in vivo," European Journal of Medicinal Chemistry, vol. 46, no. 10, pp. 4957-4963, 2011.

[17] W. M. Motswainyana, M. O. Onani, A. M. Madiehe, M. Saibu, J. Jacobs, and L. Van Meervelt, "Imino-quinolyl palladium(II) and platinum(II) complexes: synthesis, characterization, molecular structures and cytotoxic effect," Inorganica Chimica Acta, vol. 400, pp. 197-202, 2013.

[18] J. W. Williams, Y. Qu, G. H. Bulluss, E. Alvorado, and N. P. Farrell, "Dinuclear platinum complexes with biological relevance based on the 1,2-diaminocyclohexane carrier ligand," Inorganic Chemistry, vol. 46, no. 15, pp. 5820-5822, 2007.

[19] A. S. Abu-Surrah, H. H. Al-Sa'doni, and M. Y. Abdalla, "Palladium-based chemotherapeutic agents: routes toward complexes with good antitumor activity," Cancer Therapy, vol. 6, no. 6, pp. 1-10, 2008.

[20] N. Raman and S. Sobha, "Exploring the DNA binding mode of transition metal based biologically active compounds," Spectrochimica Acta Part A: Molecular and Biomolecular Spectroscopy, vol. 85, no. 1, pp. 223-234, 2012.

[21] M. Ashfaq, T. Najam, S. S. A. Shah et al., "DNA binding mode of transition metal complexes, a relationship to tumor cell toxicity," Current Medicinal Chemistry, vol. 21, no. 26, pp. 3081-3094, 2014.

[22] S. Olsztynska and M. Komorowska, Biomedical Engineering: Trends, Research and Technologies, IntechOpen, London, UK, 2011.

[23] S. S. Babkina and N. A. Ulakhovich, "Complexing of heavy metals with DNA and new bioaffinity method of their determination based on amperometric DNA-based biosensor," Analytical Chemistry, vol. 77, no. 17, pp. 5678-5685, 2005.

[24] I. D. Kuntz Jr, F. P. Gasparro, M. D. Johnston Jr, and R. P. Taylor, "Molecular interactions and the Benesi-Hildebrand equation," Journal of the American Chemical Society, vol. 90, no. 18, pp. 4778-4781, 1968.

[25] A. M. Pyle, J. P. Rehmann, R. Meshoyrer, C. V. Kumar, N. J. Turro, and J. K. Barton, "Mixed-ligand complexes of ruthenium (II): factors governing binding to DNA," Journal of the American Chemical Society, vol. 111, no. 8, pp. 3051-3058, 1989.

[26] N. Arshad, M. H. Bhatti, S. I. Farooqi, S. Saleem, and B. Mirza, "Synthesis, photochemical and electrochemical studies on triphenyltin(IV) derivative of (Z)-4-(4-cyanophenylamino)4-oxobut-2-enoic acid for its binding with DNA: biological interpretation," Arabian Journal of Chemistry, vol. 9, no. 3, pp. 451-462, 2016.

[27] J.-B. LePecq and C. Paoletti, "A fluorescent complex between ethidium bromide and nucleic acids," Journal of Molecular Biology, vol. 27, no. 1, pp. 87-106, 1967.

[28] M. S. Ibrahim, I. S. Shehatta, and A. A. Al-Nayeli, "Voltammetric studies of the interaction of lumazine with cyclodextrins and DNA," Journal of Pharmaceutical and Biomedical Analysis, vol. 28, no. 2, pp. 217-225, 2002.

[29] M. Aslanoglu, "Electrochemical and spectroscopic studies of the interaction of proflavine with DNA," Analytical Sciences, vol. 22, no. 3, pp. 439-443, 2006.

[30] Z.-H. Xu, F.-J. Chen, P.-X. Xi, X.-H. Liu, and Z.-Z. Zeng, "Synthesis, characterization, and DNA-binding properties of the cobalt(II) and nickel(II) complexes with salicylaldehyde 2- phenylquinoline-4-carboylhydrazone," Journal of Photochemistry and Photobiology A: Chemistry, vol. 196, no. 1, pp. 77-83, 2008. 